\title{
Addressing Co-occurring Suicidal Thoughts and Behaviors and Posttraumatic Stress Disorder in Evidence-Based Psychotherapies for Adults: A Systematic Review
}

David C. Rozek ${ }^{1}$, Shelby N. Baker ${ }^{1}$, Kelsi F. Rugo ${ }^{2}$, Victoria L. Steigerwald ${ }^{1}$, Lauren M. Sippel $^{3,4}$, Ryan Holliday ${ }^{5,6}$, Erika M. Roberge ${ }^{2,8}$, Philip Held ${ }^{8}$, Natalie Mota ${ }^{9}$, Noelle B. Smith ${ }^{10,11}$

${ }^{1}$ UCF RESTORES and Department of Psychology, University of Central Florida, FL ${ }^{2}$ University of Utah, Salt Lake City, UT

${ }^{3}$ National Center for PTSD, White River Junction, VT

${ }^{4}$ Department of Psychiatry, Geisel School of Medicine at Dartmouth, Hanover, NH ${ }^{5}$ Rocky Mountain Mental Illness Research, Education and Clinical Center for Veteran Suicide Prevention, Aurora, CO

${ }^{6}$ University of Colorado Anschutz Medical Campus, Aurora CO

${ }^{7}$ George E. Wahlen Veterans Affairs Medical Center, Salt Lake City, UT

${ }^{8}$ Department of Psychiatry and Behavioral Sciences, Rush University Medical Center, IL

${ }^{9}$ Departments of Clinical Health Psychology and Psychiatry, University of Manitoba ${ }^{10}$ VA Northeast Program Evaluation Center, West Haven, CT, USA

${ }^{11}$ Yale School of Medicine, New Haven, CT, USA

NOTE: This paper has been accepted for publication and is in press at the Journal of Traumatic Stress as of September 14, 2021.

Corresponding Author:

David C. Rozek

UCF RESTORES and

Department of Psychology

University of Central Florida

Orlando, FL 32816

david.rozek@ucf.edu 


\section{Author Note}

David C. Rozek iD https://orcid.org/0000-0002-0919-4919

Shelby N. Baker iD https://orcid.org/0000-0001-8561-1289

Kelsi F. Rugo (iD https://orcid.org/0000-0001-6936-2681

Victoria L. Steigerwald (iD https://orcid.org/0000-0002-5724-1257

Lauren M. Sippel iD https://orcid.org/0000-0001-7056-5857

Ryan Holliday (iD https://orcid.org/0000-0002-9896-1904

Erika M. Roberge (iD https://orcid.org/0000-0001-9102-7193

Philip Held (iD https://orcid.org/0000-0003-3974-1802

Natalie Mota iD https://orcid.org/0000-0003-2832-2223

Noelle B. Smith

Declaration of Conflicting Interests: The authors declare that there is no conflict of interest.

Disclaimer: The views expressed in this article are solely those of the authors and do not reflect an endorsement by or the official policy of the Department of Veterans Affairs or the U.S. Government.

Acknowledgements: We would like to thank David Kruidenier for his help with creating the search terms used in the systematic review. His expertise were invaluable in this process. 


\begin{abstract}
Posttraumatic stress disorder (PTSD) is a well-established risk factor for suicidal thoughts and behaviors. Historically, guidelines for treating PTSD have recommended against the use of trauma-focused therapies with patients who are high-risk for suicide likely due to concerns about potential suicide-related iatrogenesis, specifically the "triggering" of suicidal behaviors. This systematic review examines evidence for the impact of treatments specifically designed to treat PTSD or suicide on both PTSD- and suicide-related outcomes. The Preferred Reporting Items for Systematic Reviews and Meta-Analyses (PRISMA) guidelines were followed and a total of 33 articles met full inclusion criteria, of which 23 examined PTSD treatments, 4 examined suicidefocused treatments, and 6 examined combined treatments. PTSD and combined treatments reduced both PTSD- and suicide-related outcomes, with most studies examining Cognitive Processing Therapy or Prolonged Exposure. Suicide-focused treatments (e.g., cognitive therapies for suicide prevention) also reduced suicide-related outcomes, but findings were mixed for their impact on PTSD-related outcomes. Overall, PTSD treatments had the most support, primarily due to a larger number of studies examining their outcomes. This supports current clinical guidelines, which suggest utilizing PTSD treatments for individuals at risk for suicide and who have PTSD. Suicide-focused and combined treatments also appeared to be promising formats although additional research is needed. Future research should seek to compare the effectiveness of the approaches to the treatment of PTSD and suicidal thoughts and behaviors concurrently, as well as to inform guidelines aimed at supporting decisions about the selection of an appropriate treatment approach.
\end{abstract}


Posttraumatic stress disorder (PTSD) is a well-established risk factor for suicidal thoughts and behavior, inclusive of suicidal ideation, attempts, deaths, as well as suicide-related inpatient hospitalization admissions (e.g., Holliday et al., 2020; May \& Klonsky, 2016 Nock et al., 2009; Roberge et al., 2020; Panagioti et al., 2012; Stanley et al., 2021). Patients with more severe PTSD report more severe suicidal ideation and engage in more suicidal behaviors (Afzali et al., 2015; Roberge et al., 2019; Stanley et al., 2021). Moreover, PTSD is frequently associated with a number of co-occurring psychiatric conditions (e.g., depression, substance use) that are also risk factors for suicidal ideation and behaviors (Holliday et al., 2020).

Significant amounts of research funding, policy work, and clinical consideration have been dedicated to both the treatment of PTSD and management of suicide. Current clinical practice guidelines for the management of PTSD (e.g., American Psychological Association, 2017; VA/DOD, 2017) recommend trauma-focused psychotherapies including Cognitive Processing Therapy (CPT; Resick et al., 2017), Prolonged Exposure (PE; Foa et al., 2019), and Eye Movement Desensitization and Reprocessing (EMDR; Shapiro, 2018) as first-line psychotherapeutic interventions (Hamlen et al., 2019). These psychotherapies are effective at reducing PTSD symptoms in a variety of populations and in relation to different traumatic events (e.g., combat, sexual assault, physical assault, etc.; Forman-Hoffman et al., 2018).

Recent clinical guidelines for PTSD have suggested that trauma-focused treatments with individuals who are at elevated risk for suicide can be utilized (i.e., NICE, 2018; VA/DOD, 2017). However, they do not define when an individual with PTSD and risk for suicide is sufficiently "prepared" to engage in trauma-focused treatment or how to do so. One potential consequence of this lack of clear guidance is patients receiving an increased number of nontrauma-focused psychotherapeutic sessions in efforts to "prepare" or stabilize them (Holder et 
al., 2021). These interventions may be neither trauma- nor suicide-focused, thereby delaying access to evidence-based treatments (EBTs). As such, a portion of patients with PTSD who endorse suicidal thoughts and behaviors may receive delayed trauma-focused treatment, if PTSD treatment is ever initiated at all. In contrast, previous guidelines specifically recommended against the use of trauma-focused therapies with patients who are high-risk for suicide (e.g., VA/DOD, 2010; Forbes et al., 2008). These more conservative guidelines were likely influenced by the exclusion of participants at high and/or intermediate acute risk for suicide in randomized controlled trials that have typically been used to inform practice guidelines (Holliday et al., 2019; Ronconi et al., 2014). Additionally, there have been concerns for potential suicide-related iatrogenesis, specifically the "triggering" of suicidal behaviors by engaging in trauma-specific treatment (Jakupcak \& Varra, 2011).

This cautious approach likely inadvertently contributed to a considerable gap in knowledge about how to effectively manage and treat suicide risk among individuals with PTSD. This is further complicated by the fact that a valid and reliable system for categorizing suicide risk where "high" acute risk is associated with imminence of suicidal behaviors, or a tool to reliably predict suicidal behavior, does not exist (Franklin et al., 2017). Without clear empirically-informed guidance, providers and healthcare systems are left to rely on "clinical instincts" and patient reports, which can vary in validity based on several factors (e.g., patient openness to disclose). Unfortunately, the fear that many systems and providers experience in the context of managing suicide risk either significantly delays or prohibits patients from receiving PTSD treatment, and as a result, prolongs much of the suffering that likely contributes to suicidal ideation and behaviors. 
If alternative treatments for individuals with PTSD or trauma-related symptoms who are at increased risk for suicide are used, it is plausible that suicide specific clinical guidelines would be followed. The VA/DOD clinical practice guidelines for the assessment and management of patients at risk for suicide (2019) cite strong evidence for the recommendation of managing and treating suicidality with cognitive behavioral interventions focused on suicide prevention, such as Cognitive Therapy for Suicide Prevention (CT-SP; Brown et al., 2005) and Brief Cognitive Behavior Therapy for Suicide (BCBT; Rudd et al., 2015). Although other treatments such as Dialectical Behavior Therapy (DBT; Linehan, 2014), Crisis Response Planning or Safety Planning Intervention (CRP/SPI; Bryan et al., 2017, Stanley \& Brown, 2012), and problemsolving based psychotherapies (Salkovskis et al., 1990) are recommended in these guidelines, the evidence is not as strong for these therapies as it is for CT-SP and BCBT. However, these guidelines do not provide information on how to manage comorbid PTSD in high-risk individuals, nor do they discuss whether PTSD is managed by these interventions. With siloed guidelines and reviews focusing on either PTSD or suicide, clinicians are left without guidance and support on how to help patients suffering from both PTSD and suicidal thoughts and/or behaviors.

Importantly, a growing body of literature has found that suicidal ideation, as well as the beliefs that are associated with suicide risk, improves over the course of PTSD treatment (e.g., Bryan et al., 2016; Gradus et al., 2013; Holliday et al., 2018; Stayton et al., 2019). The improvement of suicidal thoughts in the context of trauma-focused therapy is unsurprising when considering their shared theoretical mechanisms of cognitive rigidity and emotion dysregulation (Bryan \& Rozek, 2017; Joseph et al., 2015). Further, recent evidence points to additional shared mechanisms and risk factors of suicide and PTSD (e.g., shame, guilt, control) (e.g., Rugo et al., 
under review). This overlap suggests that either type of treatment (i.e., trauma-focused/PTSD or suicide-focused) may improve both PTSD and suicide-related outcomes by increasing cognitive flexibility and teaching emotional regulation and coping strategies. Several reviews have focused on understanding the combined prevalence, risk, and/or mechanisms of PTSD and suicide (e.g., Holliday et al., 2020; Krysinska \& Lester, 2010; Rugo et al., under review). Although these reviews capture important information, to date, no reviews have focused specifically on treatment of co-occurring PTSD and suicidal thoughts and behaviors. Addressing this critical gap in knowledge about whether PTSD treatments and suicide-specific treatments impact both PTSD and suicide-related outcomes can inform, research, clinical care, and policies.

Therefore, the goals of the current systematic review are twofold. First, we will provide a review of the current literature of the impact of evidenced-based PTSD treatments on both PTSD- and suicide-related outcomes. Second, we will review the literature on suicide-specific treatments and their impact on PTSD- and suicide-related outcomes.

\section{Method}

This study was developed in accordance with Preferred Reporting Items for Systematic Reviews and Meta-Analyses (PRISMA) guidelines (Moher et al., 2009) and submitted for preregistration with the International Register of Systematic Reviews (PROSPERO: Registration Number Redacted for Review). We systematically searched the literature published between January 1, 1985 and January 26, 2021 within two electronic databases: PubMed and APA PsycInfo. An additional search was performed within the PTSDpubs database on June 23, 2021 to identify any studies that were missed by the original searches based on reviewer feedback (this is a deviation from the pre-registration and resulted in two additional articles being included for review). Search terms were developed in conjunction with a library science associate based on 
the search engines algorithms to capture studies that reported both PTSD and suicide outcome measures within EBTs for PTSD and suicide (see Table 1 for search terms). Duplicate studies were then merged using the reference managing software Zotero (Roy Rosenzweig Center for History and New Media, 2020). From the database search results, additional studies were identified from relevant publications found in reference lists of studies identified for inclusion. Additionally, the primary author (REMOVED FOR BLIND REVIEW) had personal correspondence with researchers who had studies related to this topic recently accepted for publication.

During the PRISMA guideline screening stage, all titles and abstracts were reviewed independently by at least two reviewers (REMOVED FOR BLIND REVIEW) who were either graduate students in a doctoral clinical psychology program or individuals who had earned a PhD in psychology. Where there were disagreements concerning eligibility, the two reviewers addressed discrepancies and either came to a consensus or brought in a third reviewer to resolve discrepancies and make a final determination. Following the abstract screening stage, the fulltext articles were independently examined for final inclusion by at least two reviewers (REMOVED FOR BLIND REVIEW). Data reviewed at this stage were: objective(s) of the study, population description, sample size for each condition, treatment description and any additional therapeutic components, PTSD outcome measure(s) and results, suicide outcome measure(s) and results, limitations, and any other important information.

Eligible studies were included based on the following criteria: 1) Published after January 1, 1985, 2) written/translated into English, 3) included an evidenced-based treatment for either PTSD as cited in clinical guidelines (e.g., CPT, PE) or suicidal thoughts and behaviors (e.g., BCBT, DBT), and 4) included outcome measures for both PTSD and suicidal thoughts and 
behaviors. Of note, studies examining only nonsuicidal self-injury (NSSI) were excluded due to NSSI being non-suicidal behavior by definition. At times, different elements of inclusion criteria were found in different studies. For example, the primary outcome paper of a clinical trial may have had the PTSD outcomes and a secondary analysis paper had the suicide-related outcomes. These papers were combined to extract all data related to the study (see Figure 1 for overview). Exclusion criteria included: 1) case studies, 2) pediatric and adolescent samples, and 3) inadequate data (i.e., no specific outcomes suicide or PTSD outcomes, only pre-treatment data on suicide or PTSD). Due to variability in the study designs, outcome measures, and populations, a meta-analytic approach was not used. Instead, a descriptive synthesis approach was conducted (Mckenzie \& Brennan, 2019), and the following descriptive data were extracted and synthesized for the current review (see Table 2) by four authors (REMOVED FOR BLIND REVIEW): sample characteristics, treatment type, supplemental components, comparison group(s), PTSD outcome measure(s), suicide outcome measure(s), and major findings.

A quality assessment was performed for each included study (REMOVED FOR BLIND REVIEW). Risk of bias was assessed using the following components of the Effective Public Health Practice Project (EPHPP) quality assessment tool (Thomas et al., 2004): selection bias, study design, confounders, data collection, and withdrawals/dropouts. To be considered of quality, analyses in the included studies were deemed as acceptable and standard quantitative analytic practices. The quality of each study was defined globally as "strong" if there were no weak component ratings, "moderate" if there was one weak component rating, and "weak" if there were two or more weak component ratings (See Table 2).

The authors categorized studies by intended focus of treatment (e.g., PTSD or traumafocused, suicide-specific, and combined treatments). For PTSD-specific treatments, the clinical 
guidelines recommendation both trauma-focused treatments (i.e., CPT, PE, EMDR, Narrative Exposure Therapy) and non-trauma focused psychotherapies (Present-Centered Therapy).

Suicide-specific treatments included protocols that targeted suicide specifically (e.g.,, cognitivebased therapies for suicide) as well as DBT based on evidence. that it targets and reduces risk for suicidal behavior and suicidal ideation (e.g., Linehan et al., 2006). Studies examining combined therapies grouped together for this review as they often combined two or more different therapies.

\section{Results}

Search terms in the PubMed and APA PsycInfo databases identified a total of 855 titles and abstracts once duplicates were removed. Following the initial screening review, 785 articles were removed due to not meeting eligibility criteria. This left 70 articles included for a full-text review, including additional articles that were found as part of follow up searches (i.e., reference mining) and author correspondence. Based on full-text review, 38 articles were excluded due to not meeting inclusion criteria and 2 articles (Bryan et al., 2016; Resick et al., 2015) were combined into 1 due to reporting on a shared dataset, and from this point forward will be presented together as one study. This resulted in 31 articles that met eligibility criteria. The subsequent search in PTSDpubs identified a total of 235 titles and abstracts after duplicates from the previous searches were removed. Following the initial screening review, 226 articles were removed due to not meeting eligibility criteria, leaving 9 articles included for a full-text review. Based on the full-text review, 7 articles were excluded, leaving 2 additional eligible articles from this review. Thus, a total of 33 articles are presented in the current systematic review. For additional details, see the PRISMA Literature Flow Diagram in Figure 1. In order to provide a descriptive examination, treatments were divided into PTSD-recommended treatments, 
combination treatments, and suicide-focused treatments. Results for specific treatments (e.g., specific EBT modalities) within each category are presented as well.

\section{Quality Assessment and Risk of Bias}

The global risk of bias ratings are presented in Table 2. Overall, the ratings of articles included for review indicated 10 studies rated as strong, 17 studies rated as moderate, and 6 studies rated as weak. The majority of studies being rated as moderate or strong is important as it gives credibility to the results. However, there are still weaknesses in the studies not captured by this rating that can have an impact on the overall results. For example, one weakness was that sample size and power estimations in clinical trials were not always presented and some studies in the current review were pilot studies with smaller samples that future research should address. Additional areas of weakness included dropout/withdrawal rates (e.g., less than $60 \%$ of participants completed the study, Simon et al., 2020; dropout/withdrawal not reported, Stayton et al., 2019) and study designs without comparison or control groups.

\section{PTSD Treatment}

\section{Overall}

Overall, PTSD treatment was associated with reductions in both PTSD- and suiciderelated outcomes. The outcomes did not appear to differ based on treatment modality, study population, trauma type, session format, or symptom measure. There were no deaths by suicide reported in any of these studies.

\section{Cognitive Processing Therapy (CPT)}

There were 11 studies that included CPT. Eight studies examined CPT only and 3 studies compared CPT to another EBT. Ten CPT studies showed reductions in both PTSD- and suiciderelated outcomes, with the majority reporting significant reductions and generally few to no 
reports of suicidal ideation or behaviors at post-treatment or at follow-up assessments. While one study reported suicide attempts by 2 participants approximately 7 months following treatment, as well as one suicide attempt from a participant who completed just one session (combined 1\% of sample), the results showed that CPT significantly reduced PTSD symptoms regardless of patients' baseline suicide risk level (Roberge et al., 2021). For all studies that compared CPT to other EBTs, both EBTs resulted in improvement in PTSD and suicide outcomes. Gradus and colleagues (2013) found improvements in suicide-related outcomes for those in CPT and PE, and Resick et al. (2015) found greater improvements in PTSD symptoms for those in the CPT group compared to Present Centered Therapy (PCT).

Overall patterns of outcomes remained the same regardless of the format in which CPT was delivered (i.e., massed or daily treatment, weekly, individual, group), trauma type, or whom it was delivered to, although populations within studies were predominantly military personnel and/or veterans. One study included civilians and one study looked at women rape survivors only.

\section{Prolonged Exposure (PE)}

There were 9 studies that included PE. One study examined PE only, 5 studies compared PE to another EBT, 1 study compared PE to PE + Sertraline, 1 study integrated PE and virtual reality exposure (VRE), and 1 study integrated PE with CBT content into a manualized protocol for primary care. Six PE studies showed reductions in both PTSD- and suicide-related outcomes, with little to no exacerbation of suicidal ideation or behaviors following treatment. One study reported that adverse events (i.e., self-harm, suicide attempts, crisis contact, and psychiatric hospitalization) during treatment and follow-up in both PE and EMDR trauma-focused groups as well as the waitlist condition were comparable but less common in the trauma-treatment groups. 
Another study reported no adverse events following treatment, and 1 reported no suicide-related outcomes at baseline or at follow-up. One study had longer-term follow-up (i.e., 6-months) that showed an increase in suicidal ideation from post-treatment to follow-up. Like CPT, the formats for PE treatment varied (e.g., standard weekly sessions, massed, virtual reality). All but one study, which combined group and individual treatment (Post et al., in press), delivered treatment in individual settings. The populations in these studies included military personnel or veterans, women rape survivors, and individuals with PTSD and psychosis or current psychotic symptoms.

\section{Eye Movement Desensitization and Reprocessing (EMDR)}

There were 4 studies that included EMDR. Two studies examined EMDR only, and 2 studies compared EMDR to another EBT. Of these studies, 1 showed significant reductions in both PTSD and suicidal ideation. The study by van der Berg and colleagues (2016) found adverse events (e.g., suicide attempts, crisis contact, psychiatric hospitalization) occurring during-treatment and at follow-up for both PE and EMDR trauma-focused groups and the waitlist condition were comparable but less common in the trauma-focused groups. The 2 other studies reported significant improvement in PTSD scores and no reports of adverse events. EMDR was delivered in a variety of formats (e.g., individual, weekly, biweekly). Populations treated included women with child abuse histories and individuals with PTSD and schizophrenia spectrum disorder, psychosis, or current psychotic symptoms.

\section{Present Centered Therapy (PCT)}

PCT is a second-line treatment for PTSD (e.g., VA/DOD, 2017) and there were 2 studies in this review that included PCT, both of which compared PCT to another EBT. Overall, these studies resulted in reductions in both PTSD- and suicide-related symptoms from pre- to posttreatment. One study reported an increase in suicidal ideation from post-treatment to 6-month 
follow-up. Treatment was delivered in a weekly or biweekly individual format and these studies included military populations.

Narrative Exposure Therapy (NET)

One study examined NET (Steuwe et al., 2016), which resulted in a significant reduction in PTSD symptoms from pre- to post-treatment. Suicide-related symptoms were measured through observation, and there were no suicide attempts reported among participants.

\section{Concurrent Treatment of PTSD and Substance Use Disorders (COPE)}

Two studies included COPE, which integrates PE with relapse prevention. One study examined COPE only and the other compared COPE to Seeking Safety. For both studies, PTSD symptoms were significantly reduced and SI was not exacerbated. Tripp et al. (2020) reported that COPE, an exposure-based intervention, did not exacerbate symptoms of PTSD and suicidal ideation at higher rates than Seeking Safety, a non-exposure-based intervention. Treatment was delivered in individual format and populations in these studies included individuals with PTSD and alcohol-related disorders.

\section{Combined PTSD \& Suicide Treatment}

\section{Overall}

Treatments that combined PTSD and suicide treatment appeared to result in reductions in PTSD symptoms and suicidal thoughts and behaviors. There were low rates of exacerbations of symptoms, adverse outcomes, and reports of suicidal thoughts and behaviors. The combining of treatments appears to be burgeoning and does not have consistent terms used for treatments.

Dialectical Behavior Therapy and Prolonged Exposure (DBT-PE) \& Dialectical Behavior Therapy for PTSD (DBT-PTSD) 
There were 6 articles that included combined DBT and exposure therapy. Three articles compared DBT+DBT PE to DBT, 1 study examined DBT-PE only, and 2 studies examined DBT-PTSD. With regard to the former 3 articles, it should be noted that one (Harned et al., 2018) is comprised of the samples from the other two articles (Harned et al., 2012 and Harned et al., 2014). Of note, the DBT protocols varied in that some delivered sequential treatment while others were more integrative in nature. Specifically, the DBT PE protocol used in the Harned et al. $(2012,2014,2018)$ papers was sequential in nature, such that DBT was delivered first for approximately one year, followed by PE. The DBT PE protocol used by Meyers et al (2017) consisted of the full DBT protocol while simultaneously delivering PE during a 12-week intensive outpatient program (IOP). Across studies there were reductions in both PTSD- and suicide-related symptoms from pre- to post-treatment. Compared to DBT only, DBT+DBT PE, sequentially, resulted in greater improvements in PTSD as well as lower rates in suicide attempts and two studies reported no exacerbations in suicide or self-injurious behaviors. In the DBT-PE concurrent treatment (Meyers et al., 2017), there were no reports of adverse events including suicide attempts or hospitalizations. The DBT-PTSD models used by Bohus et al. (2013) and Steil et al. (2018) utilized core DBT components (e.g., basic assumptions, rules, methodology, etc.) integrated with exposure-based and cognitive interventions into the modular treatment. Both studies resulted in reductions in PTSD symptoms and no exacerbations in suicide attempts or ideation.

\section{Suicide-Specific Treatment}

\section{Overall}

Suicide-specific treatments appeared to reduce suicide-related outcomes, but results were mixed for PTSD symptoms. 


\section{Brief Cognitive Behavioral Therapy for Suicide Prevention (BCBT)}

One study examined BCBT only (Rudd et al., 2015), which showed reductions in both PTSD- and suicide-related symptoms for active duty military personnel. Specifically, participants in the BCBT group compared to treatment as usual were $60 \%$ less likely to have a suicide attempt during the two year follow-up period, and there was a significant difference between groups in suicide attempts at 6 months follow-up. BCBT appears to have reduced PTSD symptoms at rates similar to treatment as usual (TAU), although these symptoms returned close to pre-treatment levels at the two-year follow-up in both BCBT and TAU.

\section{Post-Admission Cognitive Therapy for the Prevention of Suicide (PACT)}

There were two studies that examined PACT with Enhanced Usual Care (EUC) to only EUC. Both showed reductions in PTSD symptoms. In addition to PTSD symptom reductions, Ghahramanlou-Holloway and colleagues (2018) found that the PACT+EUC had a greater likelihood for significant reductions when examining high-risk patients only compared to the EUC group. Other findings included a greater likelihood for those in PACT+EUC to have significant reductions in suicidal ideation, no deaths by suicide during the study, and $17 \%$ of PACT + EUC participants (compared to $25 \%$ of EUC only participants) made one or more suicide attempts during follow-up. Both studies examining PACT reported similar study characteristics and procedures.

\section{Dialectical Behavior Therapy (DBT)}

There were four studies that included DBT. One study examined DBT only and 3 articles reported on DBT compared to DBT-PE (however, as noted in the DBT-PE section, there was overlap in the samples). The majority of the studies reported reductions in PTSD- and suiciderelated symptoms. One study reported reductions in suicidal ideation only (Harned et al., 2010) 
and found that among those who reduced exclusionary behaviors, including suicide and suicidal ideation, the majority still met criteria for PTSD at the end of treatment, though the presence of co-occurring PTSD did not lessen the impact of DBT on suicide risk. The other 3 articles reported no exacerbations in suicide behaviors. Study samples were comprised predominately of women with PTSD symptoms or diagnoses, borderline personality disorder (BPD), and suiciderelated behaviors.

\section{Discussion}

In this systematic review, we examined the existing literature for 1) the impact of evidence-based PTSD treatments on suicide-related outcomes, 2) the impact of suicide-specific treatments on PTSD outcomes with the goal of informing researchers, clinicians, and policy makers about the available data related to these treatment options for individuals with PTSD and heightened suicide risk.

Through the review process, a third category of PTSD- and suicide-specific combined treatments (e.g., DBT-PE or DBT-PTSD) emerged and was examined for simultaneous reductions in PTSD- and suicide-related symptoms. Overall, whether treatment was for PTSD, suicide-specific, or combined, EBTs examined in this systematic review showed promising results in reducing both PTSD- and suicide-related symptoms. Such a finding may be indicative that these treatments act upon similar mechanisms underlying both suicide- and PTSD-related risk (e.g., cognitive reframing, coping skills to facilitate emotion regulation, emotions such as guilt, anger, shame, etc.). Importantly, trauma-focused treatments had the most research supporting these findings and additionally showed that suicide risk level does not negatively impact PTSD outcomes in trauma-focused treatment (Roberge et al., 2021). However, these overall conclusions should be couched within the context of a limited number of studies 
(specifically those examining the impact of suicide-specific treatments on PTSD symptoms), the quality assessment (e.g., majority moderate or above but with noted weaknesses), and significant heterogeneity in suicide-related outcomes and measurement.

\section{PTSD treatment}

This systematic review revealed that PTSD treatments have the most evidence showing simultaneous reductions in PTSD symptoms and suicide outcomes. Specifically, there were more CPT studies that reported on and reduced both PTSD and suicide symptoms $(n=12)$ than any other treatment modality, followed by PE $(n=9)$. It is unsurprising that PTSD treatments simultaneously reduced PTSD and suicide symptoms given that they share key treatment components. For example, both CPT and BCBT may target negative cognitions related to traumatic experiences that are often intertwined with suicidal thoughts and behaviors. Similarly, PE reduces avoidance (and other trauma-related symptoms) and increases self-efficacy and engagement in meaningful activities. These reductions in symptoms are shown to have a link (direct and indirect) to reducing suicide risk (e.g., Holliday et al., 2020). All other PTSD treatments included in this review (i.e., EMDR, $n=4$; PCT, $n=2$; COPE, $n=2$; NET, $n=1$ ) showed positive impacts on PTSD symptoms and suicide-related outcomes; however, the number of included studies was fewer, suggesting the inherent need for additional research.

\section{Suicide-specific treatment}

Concerning the second aim, this systematic review revealed that there is initial evidence to suggest suicide-specific treatments are also effective in reducing both PTSD- and suiciderelated symptoms. However, a critical limitation of this finding is that significantly fewer studies exist to support the efficacy of reducing PTSD symptoms in suicide-specific treatments. This gap in the research is expected given that a number of these studies were designed to focus on suicide 
prevention among at-risk populations, which included those exposed to trauma, rather than PTSD symptom attenuation explicitly. Although these treatments are still important treatments to have available for individuals who may not have a history of trauma or PTSD but are still at heightened risk for suicide, given the risk for suicidal behaviors of individuals with PTSD, it is likely than many individuals in other suicide-specific treatment studies had PTSD or symptoms of PTSD but that was not reported or the focus of the trials.

In particular, both $\mathrm{BCBT}(n=1)$ and PACT $(n=2)$ are treatments that show a reduction of both PTSD symptoms and suicide outcomes. The evidence reported in this review is promising for these treatments in managing suicide while reducing PTSD symptomology. Of note, the longer-term follow-up, 18-months in BCBT, showed PTSD symptoms returning to similar levels as pre-treatment. The sample in the BCBT trial had $\sim 1 / 3$ of participants diagnosed with PTSD, meaning the majority of participants did not have a trauma-specific diagnosis. These suicide-specific treatments may be useful in treating PTSD symptoms and may require additional treatment or revisions to be most effective for individuals with both PTSD and high risk for suicide. They may be best used as they were designed - for individuals who have suicide as the primary concern and they can still help reduce PTSD symptoms for those with related diagnoses.

We also examined DBT as a suicide-specific treatment, as DBT was designed to treat severe emotion dysregulation that often results in suicidal behaviors. DBT $(n=4)$ was consistently reported to effectively reduce personality disorder-, PTSD-, and suicide-related symptoms. A caveat to DBT treatment is that, as evidenced by the studies included in this review, standard DBT is an intensive therapy (i.e., multiple hours of weekly individual therapy and skills coaching per week) that typically consists of a full year long treatment (Linehan, 1993). Though DBT was found to reduce PTSD-, suicide-, and personality disorder-related 
symptoms, the inherent intensity of this treatment suggests that DBT may be a best fit for individuals who present with severe symptoms and multiple diagnoses (e.g., PTSD, suicide related symptoms, and personality disorder).

\section{Combination treatment}

The review process revealed a third category of combined PTSD and suicide-specific treatments $(n=6)$, though there is currently less existing research in this area. Earlier studies in this area utilized a sequential approach to combining treatment in which exposure-based treatments (e.g., PE) were added only after DBT was first delivered and successful in managing suicide risk (e.g., Harned et al., 2012; Harned et al., 2014). More recent research has adopted an integrative approach in which both suicide-focused (DBT) and trauma-focused (PE) treatment are delivered simultaneously starting in the first few weeks of treatment (Meyers et al., 2017), as well as DBT-PTSD protocols that integrated exposure and cognitive skills into DBT treatment (Bohus et al., 2013; Steil et al., 2018). Integrative approaches like these may be more efficient while maintaining desired symptom reductions and, despite requiring more research, they are a promising medium for treating commonly comorbid mental health concerns.

\section{Integration of Findings and Future Directions}

As indicated by the current literature, EBTs for PTSD (e.g.,., CPT and PE) are effective in reducing suicidal ideation and behaviors and may be the best fitting treatment for someone with PTSD or other trauma-related disorders. A promising avenue for further reducing cooccurring PTSD and suicide risk is the integration of brief suicide-specific interventions into existing trauma-focused treatments (e.g., Rozek \& Bryan, 2020). This approach, if supported by evidence from well-controlled trials, could have great benefits to patients, clinicians, and organizations. Given that there is less research on suicide-specific treatments managing PTSD 
symptoms and that the evidence available, while supportive, may not have as lasting effects, a more fully integrated model of these treatments may provide the best outcomes possible for individuals with PTSD and heightened suicide risk.

This integrative model may reduce some burden and barriers to individuals who have PTSD and are at increased risk for suicide. If a patient is provided with suicide-specific treatment prior to PTSD treatment, the individual may have to go through two full courses of treatment. Although this may be useful and necessary for some individuals, if there is a way to best integrate these practices, we may lessen the burden on these individuals by reducing the financial, time (i.e., time spent in treatment), cognitive, and emotional burden that patients may experience in sequential approaches.

As seen in the DBT-PE and the integrated DBT-PTSD studies, true integration can occur in treatment. Given the overlap in conceptual interventions across trauma-focused treatments and suicide-specific treatments, a potential new therapy that integrates these components and provides guidance on how to focus on both PTSD and suicide within the same treatment is critical. This may mean that, similar to DBT-PTSD, the integration of different content of BCBT or PACT into CPT and/or PE to create a modified or new treatment for high-risk individuals at risk for suicide may be a promising treatment avenue. Alternatively, foundational components of suicide-specific treatments that are referenced in clinical practice guidelines (VA/DOD, 2019) including Crisis Response Planning (CRP; Bryan et al., 2017) and the Safety Plan Intervention (SPI; Stanley \& Brown, 2012) are interventions that can be easily integrated into many treatments and are main components of suicide-specific treatments (i.e., BCBT and PACT). These interventions have been shown to reduce suicidal behaviors by $45-76 \%$ as a stand-alone intervention and improve other protective factors (Bryan et al., 2017; Rozek et al., 2019; Stanley 
et al., 2018). Preliminary work has suggested using a CRP during trauma-focused treatment is feasible (Rozek \& Bryan, 2020). Both the CRP and SPI are easily integrated into other traumafocused treatments without undermining the fidelity of the original treatment. Future research should focus on understanding what components of suicide-specific treatments are most effective at reducing suicidal behavior and risk and then integrate these components in trauma-focused treatments.

Alternatively, a more specific focus on the integration of addressing suicidal thoughts and behaviors into other types of treatment could be done. The integration of DBT and PE has been combined in several different models as noted in the review. However, another type of integration could be to modify different protocols to have a specific suicide prevention component that fits within the treatment modality. For example, there could be the development of CPT for Suicide Prevention (CPT-SP). In this protocol, patients could go through the standard treatment with minor modifications such as assigning homework specific to the suicide related cognitions in addition to the trauma-focused cognitions. A module on suicide could be added to the current standard modules (i.e., safety, trust, power/control, esteem, and intimacy). Training and implementation of this type of treatment would focus on how to discuss suicidal cognitions and ensuring that they are an integrated part of treatment. Future research could examine integration of a focus on suicide and trauma for trauma-focused treatments.

Assessment of risk for suicide throughout treatment is critical for determining if additional intervention or modification of intervention should be considered. There are various pros and cons to developing a new treatment protocol versus the integration of brief suicide specific interventions into other established treatments. For example, if a patient discloses suicide risk in the middle of a treatment protocol, the integration of a brief suicide specific 
intervention may be more appropriate than abruptly transitioning to a new protocol with a different focus. Ideally, the provider would integrate suicide prevention interventions such as safety plans into the session as seamlessly as possible. Future research can test whether novel integrated treatments for PTSD and suicide for individuals with heightened risk for suicide have a larger impact on suicidality than stand-alone treatments for PTSD or suicide.

The recent update in clinical practice guidelines was the first step in moving this area of treatment and research forward (VA/DOD, 2017, 2019). The current review supports these guidelines and provides a more in-depth review of how both PTSD- and suicide-related outcomes are reduced in trauma-focused and PTSD treatments. More guidance is needed to understand the best practices of using trauma-focused treatments with high-risk individuals and how to use suicide-specific treatments to help manage PTSD symptoms. Additionally, research and funding should target these areas including but not limited to testing slight modifications of already developed treatments, the integration of suicide specific treatment into trauma-focused treatments (e.g., components or full treatment), and/or understanding sequencing treatments effectively. These results will have a significant impact on policies in mental healthcare.

\section{Limitations}

The findings of this systematic review should be interpreted within the context of several limitations. Certain treatments were underrepresented in the included studies, and the conclusions relating to these treatments should therefore be considered preliminary. Specifically, few suicide-specific treatment studies that met inclusion criteria reported PTSD outcomes. This was to be expected as these treatments were developed to specifically target suicide risk, which does not always co-occur with PTSD. With respect to PTSD treatments, EMDR, PCT, COPE/SS, and NET were underrepresented relative to CPT and PE. Although these treatments did 
demonstrate reductions in both PTSD- and suicide-related symptoms, further research is needed to determine the effectiveness of these treatments for individuals with co-occurring PTSD and suicidal thoughts and behaviors in studies that are developed to target these areas. Further, a confounding variable within this research is potential pharmacologic or other therapeutic intervention. The likelihood of study participants taking medication in conjunction with psychotherapy or engaging in other therapeutic practice should be considered when interpreting these findings as clinical guidelines also provide information on best pharmacological practices (e.g., VA/DOD, 2017).

Additionally, included studies used varied measures of suicide-related outcomes, with some focusing on single-item measurement (e.g., PHQ-9 item 9) and others focusing on documented or reported behaviors (e.g., adverse events). Measurement of suicide risk and the difference between suicidal ideation and behaviors is an area that needs further research (e.g., Brown et al., 2020; Tabares et al., 2020). It is possible that there are floor effects on some of these measures of suicide risk with the addition of earlier clinical guidelines suggesting exclusion of these individuals from treatment for PTSD. Differing use of self-report, clinicianadministered, and observational measures of suicidal thoughts and behaviors and adverse events limited our ability to compare suicide-related outcomes across treatments. Due to these differences, it is sometimes hard to quantify the risk level of patients, making it problematic in determining how these treatments impact different aspects of suicide risk. Future research needs to take a more fine-grained approach to examining suicide risk including the development of new measures, as even common screeners of suicide have been shown to not perform well (e.g., Brown et al., 2020). Suicidal ideation is a risk factor for suicide and yet is distinct from suicidal behavior. Related to suicide outcome assessment, many trials included the limitation that high- 
risk suicidal individuals were excluded with an emphasis on acute suicide risk (i.e., imminent danger), although other studies noted a range of risk levels. Additionally, although the majority of the studies were moderate in the quality rating, larger scale trials that are well designed are necessary to provide updates to clinical guidelines on these important topics. Studies were commonly limited by small sizes and observational designs, highlighting a need for more robust, randomized studies of PTSD- and suicide-specific treatments.

As with many clinical trials, there is a need for additional research on underrepresented groups to ensure that these treatments truly have the same effect across groups. In terms of treatments and study data, it is possible that other treatments that are suicide-specific (e.g., Collaborative Assessment and Management of Suicidality; Jobes et al., 2017) also impact PTSD but has not currently been reported in the literature. Similarly, suicide related outcomes may have been captured in PTSD treatment trials but not reported in publications. Future research should work towards having common data elements for treatments related to suicide and PTSD. This study is further limited to the search results from the three databases, and results do not include gray literature (i.e., articles not accepted for publication). Of note, the included studies were all conducted in the Western hemisphere and mostly based in the United States of America with many studies also being focused on military personnel. Additional research should focus on how cultural factors could impact these results and how these data might look in a global sample. Finally, due to heterogeneity in sample, design, and outcome measures, we were unable to compare the outcomes of the included studies using a meta-analytic approach. Although there are several limitations, the current review provides an overview of the current state of the research and provides future directions that can improve this area to help impact treatment, guidelines, and policies related to high-risk individuals with PTSD. 


\section{Conclusion and Clinical Implications}

Our findings indicate that PTSD-specific, suicide-specific, and combined treatments appear to have a positive impact on PTSD- and suicide-related symptoms. The most research showing these effects has been done in trauma-focused treatments including both CPT and PE. Recent clinical guidelines have suggested that individuals with heightened risk for suicide can be provided trauma-focused treatments. Future research should focus on providing additional guidance on best practices for treating co-occurring PTSD and suicide risk. This may include modifying treatments, integrating treatments, and/or developing new treatments to increase effectiveness. Future clinical guidelines may be even more useful to providers if they are "unsiloed" and instead integrated (i.e., clinical guidelines for PTSD that include extensive integration and discussion of suicide related treatments). Overall, clinicians and researchers should continue to treat these individuals with the evidence-based treatments available in order to target PTSD and suicide risk to help alleviate their suffering. 


\section{References}

Articles included in review indicated by * and related article **.

Afzali, M. H., Birmes, P., \& Vautier, S. (2015). Symptoms moderating the association between recent suicide attempts and trauma levels: Fan-shaped effects. Death Studies, 39(10), 654-662. https://doi.org/10.1080/07481187.2015.1047063

American Psychological Association. (2017). Clinical Practice Guideline for the Treatment of Posttraumatic Stress Disorder (PTSD) in Adults. Washington DC: American Psychological Association.

*Blain, R. C., Pukay-Martin, N. D., Martin, C. E., Dutton-Cox, C. E., \& Chard, K. M. (2020). Residential Cognitive Processing Therapy Decreases Suicidality by Reducing Perceived Burdensomeness in Veterans with Posttraumatic Stress Disorder. Journal of Traumatic Stress, 0, 1-10. https://doi.org/10.1002/jts.22618

*Bohus, M., Dyer, A. S., Priebe, K., Krüger, A., Kleindienst, N., Schmahl, C., Niedtfeld, I., \& Steil, R. (2013). dialectical behaviour therapy for post-traumatic stress disorder after childhood sexual abuse in patients with and without borderline personality disorder: A randomised controlled trial. Psychotherapy and Psychosomatics, 82(4), 221-233. https://doi.org/10.1159/000348451

Brown, G. K., Ten Have, T., Henriques, G. R., Xie, S. X., Hollander, J. E., \& Beck, A. T. (2005). Cognitive Therapy for the Prevention of Suicide Attempts: A Randomized Controlled Trial. JAMA, 294(5), 563. https://doi.org/10.1001/jama.294.5.563

Brown, L. A., Boudreaux, E. D., Arias, S. A., Miller, I. W., May, A. M., Camargo, C. A., Bryan, C. J., \& Armey, M. F. (2020). C-SSRS performance in emergency department patients at 
high risk for suicide. Suicide and Life-Threatening Behavior, 50(6), 1097-1104. https://doi.org/10.1111/sltb.12657

*Brown, L. A., McLean, C. P., Zang, Y., Zandberg, L., Mintz, J., Yarvis, J. S., Litz, B. T., Peterson, A. L., Bryan, C. J., Fina, B., Petersen, J., Dondanville, K. A., Roache, J. D., Young-McCaughan, S., \& Foa, E. B. (2019). Does prolonged exposure increase suicide risk? Results from an active duty military sample. Behaviour Research and Therapy, 118, 87-93. https://doi.org/10.1016/j.brat.2019.04.003

*Bryan, C. J., Clemans, T. A., Hernandez, A. M., Mintz, J., Peterson, A. L., Yarvis, J. S., Resick, P. A., \& The STRONG STAR Consortium. (2016). Evaluating potential iatrogenic suicide risk in trauma-focused group cognitive behavioral therapy for the treatment of PTSD in active duty military personnel: Research Article: Suicide Risk in Group CPT. Depression and Anxiety, 33(6), 549-557. https://doi.org/10.1002/da.22456

*Bryan, C. J., Leifker, F. R., Rozek, D. C., Bryan, A. O., Reynolds, M. L., Oakey, D. N., \& Roberge, E. (2018). Examining the effectiveness of an intensive, 2-week treatment program for military personnel and veterans with PTSD: Results of a pilot, open-label, prospective cohort trial: BRYAN ET AL . Journal of Clinical Psychology, 74(12), 20702081. https://doi.org/10.1002/jclp.22651

Bryan, C. J., Mintz, J., Clemans, T. A., Leeson, B., Burch, T. S., Williams, S. R., Maney, E., \& Rudd, M. D. (2017). Effect of crisis response planning vs. contracts for safety on suicide risk in U.S. Army Soldiers: A randomized clinical trial. Journal of Affective Disorders, 212, 64-72. https://doi.org/10.1016/j.jad.2017.01.028 
Bryan, C. J., \& Rozek, D. C. (2018). Suicide prevention in the military: A mechanistic perspective. Current Opinion in Psychology, 22, 27-32. https://doi.org/10.1016/j.copsyc.2017.07.022

Bullman, T.A., \& Kang, H.K. (1994). Posttraumatic stress disorder and the risk of traumatic deaths among Vietnam veterans. Journal of Nervous and Mental Disease, 182, 604-610. http://doi.10.1097/00005053-199411000-00002

*Cigrang, J. A., Rauch, S. A. M., Avila, L. L., Bryan, C. J., Goodie, J. L., Hryshko-Mullen, A., Peterson, A. L., \& STRONG STAR Consortium. (2011). Treatment of active-duty military with PTSD in primary care: Early findings. Psychological Services, 8(2), 104113. https://doi.org/10.1037/a0022740

*Cox, K. S., Mouilso, E. R., Venners, M. R., Defever, M. E., Duvivier, L., Rauch, S. A. M., Strom, T. Q., Joiner, T. E., \& Tuerk, P. W. (2016). Reducing suicidal ideation through evidence-based treatment for posttraumatic stress disorder. Journal of Psychiatric Research, 80, 59-63. https://doi.org/10.1016/j.jpsychires.2016.05.011

Department of Veterans Affairs \& Department of Defense. (2010). VA/DoD clinical practice guideline for management of posttraumatic stress. Washington, DC: Department of Veterans Affairs and Department of Defense.

Department of Veterans Affairs \& Department of Defense Clinical Practice Guideline Working Group. (2017). VA/DoD Clinical Practice Guideline for the Management of Posttraumatic Stress Disorder and Acute Stress Disorder. Washington, DC: VA Office of Quality and Performance.

*de Bont, P. A. J. M., van Minnen, A., \& de Jongh, A. (2013). Treating PTSD in patients with 
psychosis: A Within-group controlled feasibility study examining the efficacy and safety of evidence-based PE and EMDR protocols. Behavior Therapy, 44(4), 717-730. https://doi.org/10.1016/j.beth.2013.07.002

Foa, E. B, Hembree, E., Rothbaum, B. O., \& Rauch, S. A. M. (2019). Prolonged exposure therapy for PTSD: Emotional processing of traumatic experiences (second edition). Oxford University Press.

**Foa, Edna B., McLean, C. P., Zang, Y., Rosenfield, D., Yadin, E., Yarvis, J. S., Mintz, J., Young-McCaughan, S., Borah, E. V., Dondanville, K. A., Fina, B. A., Hall-Clark, B. N., Lichner, T., Litz, B. T., Roache, J., Wright, E. C., Peterson, A. L., \& for the STRONG STAR Consortium. (2018). Effect of prolonged exposure therapy delivered over 2 weeks vs 8 weeks vs present-centered therapy on PTSD symptom severity in military personnel: A randomized clinical trial. JAMA, 319(4), 354. https://doi.org/10.1001/jama.2017.21242

Forman-Hoffman, V., Cook Middleton, J., Feltner, C., Gaynes, B. N., Palmieri Weber, R., Bann, C., Viswanathan, M., Lohr, K. N., Baker, C., \& Green, J. (2018). Psychological and pharmacological treatments for adults with posttraumatic stress disorder: A systematic review update. Agency for Healthcare Research and Quality (AHRQ). https://doi.org/10.23970/AHRQEPCCER207

Franklin, J. C., Ribeiro, J. D., Fox, K. R., Bentley, K. H., Kleiman, E. M., Huang, X., Musacchio, K. M., Jaroszewski, A. C., Chang, B. P., \& Nock, M. K. (2017). Risk factors for suicidal thoughts and behaviors: A meta-analysis of 50 years of research. Psychological Bulletin, 143(2), 187-232. https://doi.org/10.1037/bul0000084

*Ghahramanlou-Holloway, M., LaCroix, J. M., Perera, K. U., Neely, L., Grammer, G., Weaver, J., Novak, L. A., Colborn, V., \& Lee-Tauler, S. Y. (2020). Inpatient psychiatric care 
following a suicide-related hospitalization: A pilot trial of Post-Admission Cognitive Therapy in a military medical center. General Hospital Psychiatry, 63, 46-53. https://doi.org/10.1016/j.genhosppsych.2018.11.006

*Gradus, J. L., Suvak, M. K., Wisco, B. E., Marx, B. P., \& Resick, P. A. (2013). Treatment of posttraumatic stress disorder reduces suicidal ideation. Depression and Anxiety, 30, 1046-1053. https://doi.org/10.1002/da.22117

Hamblen, J. L., Norman, S. B., Sonis, J. H., Phelps, A. J., Bisson, J. I., Nunes, V. D., MegninViggars, O., Forbes, D., Riggs, D. S., \& Schnurr, P. P. (2019). A guide to guidelines for the treatment of posttraumatic stress disorder in adults: An update. Psychotherapy, 56(3), 359-373. https://doi.org/10.1037/pst0000231

*Harned, M. S., Gallop, R. J., \& Valenstein-Mah, H. R. (2018). What changes when? The course of improvement during a stage-based treatment for suicidal and self-injuring women with borderline personality disorder and PTSD. Psychotherapy Research, 28(5), 761-775. https://doi.org/10.1080/10503307.2016.1252865

*Harned, M. S., Jackson, S. C., Comtois, K. A., \& Linehan, M. M. (2010). Dialectical behavior therapy as a precursor to PTSD treatment for suicidal and/or self-injuring women with borderline personality disorder: DBT as a Precursor to PTSD Treatment. Journal of Traumatic Stress, 23(4), 421-429. https://doi.org/10.1002/jts.20553

*Harned, M. S., Korslund, K. E., Foa, E. B., \& Linehan, M. M. (2012). Treating PTSD in suicidal and self-injuring women with borderline personality disorder: Development and preliminary evaluation of a Dialectical Behavior Therapy Prolonged Exposure Protocol. Behaviour Research and Therapy, 50(6), 381-386.

https://doi.org/10.1016/j.brat.2012.02.011 
*Harned, M. S., Korslund, K. E., \& Linehan, M. M. (2014). A pilot randomized controlled trial of Dialectical Behavior Therapy with and without the Dialectical Behavior Therapy Prolonged Exposure protocol for suicidal and self-injuring women with borderline personality disorder and PTSD. Behaviour Research and Therapy, 55, 7-17. https://doi.org/10.1016/j.brat.2014.01.008

Harned, M. S., Wilks, C. R., Schmidt, S. C., \& Coyle, T. N. (2018). Improving functional outcomes in women with borderline personality disorder and PTSD by changing PTSD severity and post-traumatic cognitions. Behaviour Research and Therapy, 103, 53-61. https://doi.org/10.1016/j.brat.2018.02.002

Holder, N., Holliday, R., Khan, A. J., Shiner, B., Neylan, T. C., Madden, E., \& Maguen, S. (2021). Influence of suicidal ideation on mental health care following risk assessment among Iraq and Afghanistan war veterans with posttraumatic stress disorder. General Hospital Psychiatry. Published Online Ahead of Print.

Holliday, R., Borges, L. M., Stearns-Yoder, K. A., Hoffberg, A. S., Brenner, L. A., \& Monteith, L. L. (2020). Posttraumatic stress disorder, suicidal ideation, and suicidal self-directed violence among U.S. military personnel and veterans: a systematic review of the literature from 2010 to 2018. Frontiers in Psychology, 11, 1998. https://doi.org/10.3389/fpsyg.2020.01998

*Holliday, R., Holder, N., Monteith, L. L., \& Surís, A. (2018). Decreases in suicide cognitions after cognitive processing therapy among veterans with posttraumatic stress disorder due to military sexual trauma: A preliminary examination. Journal of Nervous \& Mental Disease, 206(7), 575-578. https://doi.org/10.1097/NMD.0000000000000840 
Holliday, R., Holder, N., Olson-Madden, J. H., \& Monteith, L. L. (2019). Treating posttraumatic stress disorder in the presence of acute suicide risk in veterans and active duty service members: A call for research. Journal of Nervous \& Mental Disease, 207(7), 611-614. https://doi.org/10.1097/NMD.0000000000001022

*Horwitz, A. G., Held, P., Klassen, B. J., Karnik, N. S., Pollack, M. H., \& Zalta, A. K. (2018). Posttraumatic cognitions and suicidal ideation among veterans receiving PTSD treatment. Cognitive Therapy and Research, 42(5), 711-719. https://doi.org/10.1007/s10608-018$\underline{9925-6}$

Ilgen, M. A., Bohnert, A. S. B., Ignacio, R. V., McCarthy, J. F., Valenstein, M. M., Kim, H. M., \& Blow, F. C. (2010). Psychiatric diagnoses and risk of suicide in veterans. Archives of General Psychiatry, 67(11), 1152. https://doi.org/10.1001/archgenpsychiatry.2010.129

Jakupcak, M., \& Varra, E. M. (2011). Treating Iraq and Afghanistan war veterans with PTSD who are at high risk for suicide. Cognitive and Behavioral Practice, 18(1), 85-97. https://doi.org/10.1016/j.cbpra.2009.08.007

Jamshidi, F., Rajabi, S., \& Dehghani, Y. (2020). How to heal their psychological wounds? Effectiveness of EMDR therapy on post-traumatic stress symptoms, mind-wandering and suicidal ideation in Iranian child abuse victims. Counselling and Psychotherapy Research, capr.12339. https://doi.org/10.1002/capr.12339

*Johnson, C. M., Holmes, S. C., Suvak, M. K., Song, J., Shields, N., Lane, J. E. M., Sijercic, I., Cohen, Z. D., Stirman, S. W., \& Monson, C. M. (In press). The effect of PTSD symptom change on suicidal ideation in a combined military and civilian sample engaged in cognitive processing therapy. Behavior Therapy, S0005789420301404. https://doi.org/10.1016/j.beth.2020.10.001 
Joseph, J.S., Moring, J.C., Bira, L.M. (2015). Cognitive flexibility as a key factor in the conceptualization and treatment of PTSD, 11(3): 180-192.

**Krüger, A., Kleindienst, N., Priebe, K., Dyer, A. S., Steil, R., Schmahl, C., \& Bohus, M. (2014). Non-suicidal self-injury during an exposure-based treatment in patients with posttraumatic stress disorder and borderline features. Behaviour Research and Therapy, 61, 136-141. https://doi.org/10.1016/j.brat.2014.08.003

Karolina Krysinska \& David Lester (2010) Post-Traumatic Stress Disorder and Suicide Risk: A Systematic Review, Archives of Suicide Research, 14:1, 1-23, DOI: $10.1080 / 13811110903478997$

Kuffel, R., Clark, R., Neylan, T., Maguen, S., Li, Y., \& Byers, A. (2021). PTSD, risk of suicide, and unintended death by overdose in mid- to late-life. American Journal of Geriatric Psychiatry, 29, S59-S60.

*LaCroix, J. M., Perera, K. U., Neely, L. L., Grammer, G., Weaver, J., \& GhahramanlouHolloway, M. (2018). Pilot trial of post-admission cognitive therapy: Inpatient program for suicide prevention. Psychological Services, 15(3), 279-288. https://doi.org/10.1037/ser0000224

Linehan, M. M. (2017). DBT skills training manual. Guilford.

Linehan, M. M., Comtois, K. A., Murray, A. M., Brown, M. Z., Gallop, R. J., Heard, H. L., Korslund, K. E., Tutek, D. A., Reynolds, S. K., \& Lindenboim, N. (2006). Two-year randomized controlled trial and follow-up of dialectical behavior therapy vs therapy by experts for suicidal behaviors and borderline personality disorder. Archives of General Psychiatry, 63(7), 757. https://doi.org/10.1001/archpsyc.63.7.757 
May, A. M., \& Klonsky, E. D. (2016). What distinguishes suicide attempters from suicide ideators? A meta-analysis of potential factors. Clinical Psychology: Science and Practice, 23(1), 5-20. https://doi.org/10.1111/cpsp.12136

McKenzie, J. E., \& Brennan, S. E. (n.d.). Chapter 12: Synthesizing and presenting findings using other methods. In J. P. T. Higgins, J. Thomas, J. Chandler, M. Cumpston, T. Li, J. Page, \& V. A. Welch (Eds.), Cochrane Handbook for Systematic Reviews of Interventions (Version 6.0). www. training.cochrane.org/handbook

*Meyers, L., Voller, E. K., McCallum, E. B., Thuras, P., Shallcross, S., Velasquez, T., \& Meis, L. (2017). Treating veterans with PTSD and borderline personality symptoms in a 12week intensive outpatient setting: findings from a pilot program. Journal of Traumatic Stress, 30(2), 178-181. https://doi.org/10.1002/jts.22174

Moher, D., Liberati, A., Tetzlaff, J., Altman, D. G., \& The PRISMA Group. (2009). Preferred reporting items for systematic reviews and meta-analyses: The PRISMA statement. PLoS Medicine, 6(7), e1000097. https://doi.org/10.1371/journal.pmed.1000097

**Monson, C. M., Shields, N., Suvak, M. K., Lane, J. E. M., Shnaider, P., Landy, M. S. H., Wagner, A. C., Sijercic, I., Masina, T., Wanklyn, S. G., \& Stirman, S. W. (2018). A randomized controlled effectiveness trial of training strategies in cognitive processing therapy for posttraumatic stress disorder: Impact on patient outcomes. Behaviour Research and Therapy, 110, 31-40. https://doi.org/10.1016/j.brat.2018.08.007

National Institute for Health and Care Excellence (NICE). (2018). Guidleline for post-traumatic stress disorder. London, United Kingdon: National Institute for Health and Clinical Practice. 
Nock, M. K., Hwang, I., Sampson, N., Kessler, R. C., Angermeyer, M., Beautrais, A., Borges, G., Bromet, E., Bruffaerts, R., de Girolamo, G., de Graaf, R., Florescu, S., Gureje, O., Haro, J. M., Hu, C., Huang, Y., Karam, E. G., Kawakami, N., Kovess, V., ... Williams, D. R. (2009). Cross-national analysis of the associations among mental disorders and suicidal behavior: Findings from the WHO world mental health surveys. PLoS Medicine, 6(8), e1000123. https://doi.org/10.1371/journal.pmed.1000123

**Norman, S. B., Haller, M., Spadoni, A. D., Drummond, S. P. A., Risbrough, V., Hamblen, J. L., Trim, R. S., \& Blanes, E. X. (2015). Maximizing the utility of a single site randomized controlled psychotherapy trial. Contemporary Clinical Trials, 42, 244-251. https://doi.org/10.1016/j.cct.2015.04.011

**Norman, S. B., Trim, R., Haller, M., Davis, B. C., Myers, U. S., Colvonen, P. J., Blanes, E., Lyons, R., Siegel, E. Y., Angkaw, A. C., Norman, G. J., \& Mayes, T. (2019). Efficacy of integrated exposure therapy vs integrated coping skills therapy for comorbid posttraumatic stress disorder and alcohol use disorder: A randomized clinical trial. $J A M A$ Psychiatry, 76(8), 791. https://doi.org/10.1001/jamapsychiatry.2019.0638

*Norr, A. M., Smolenski, D. J., \& Reger, G. M. (2018). Effects of prolonged exposure and virtual reality exposure on suicidal ideation in active duty soldiers: An examination of potential mechanisms. Journal of Psychiatric Research, 103, 69-74. https://doi.org/10.1016/j.jpsychires.2018.05.009

Panagioti, M., Gooding, P. A., \& Tarrier, N. (2012). A meta-analysis of the association between posttraumatic stress disorder and suicidality: The role of comorbid depression. Comprehensive Psychiatry, 53(7), 915-930. https://doi.org/10.1016/j.comppsych.2012.02.009 
*Post, L., Held, P., Smith, Dale. L., Black, K., Van Horn, R., Pollack, M. H., Rothbaum, B. O., \& Rauch, S. A. M. (In press). Impact of intensive treatment programs for posttraumatic stress disorder on suicidal ideation in veterans and service members.

**Rauch, S. A. M., Kim, H. M., Powell, C., Tuerk, P. W., Simon, N. M., Acierno, R., Allard, C. B., Norman, S. B., Venners, M. R., Rothbaum, B. O., Stein, M. B., Porter, K., Martis, B., King, A. P., Liberzon, I., Phan, K. L., \& Hoge, C. W. (2019). efficacy of prolonged exposure therapy, sertraline hydrochloride, and their combination among combat veterans with posttraumatic stress disorder: A randomized clinical trial. JAMA Psychiatry, 76(2), 117. https://doi.org/10.1001/jamapsychiatry.2018.3412

**Rauch, S. A. M., Simon, N. M., Kim, H. M., Acierno, R., King, A. P., Norman, S. B., Venners, M. R., Porter, K., Phan, K. L., Tuerk, P. W., Allard, C., Liberzon, I., Rothbaum, B. O., Martis, B., Stein, M. B., \& Hoge, C. W. (2018). Integrating biological treatment mechanisms into randomized clinical trials: Design of PROGrESS (PROlonGed ExpoSure and Sertraline Trial). Contemporary Clinical Trials, 64, 128-138. https://doi.org/10.1016/j.cct.2017.10.013

**Reger, G. M., Koenen-Woods, P., Zetocha, K., Smolenski, D. J., Holloway, K. M., Rothbaum, B. O., Difede, J., Rizzo, A. A., Edwards-Stewart, A., Skopp, N. A., Mishkind, M., Reger, M. A., \& Gahm, G. A. (2016). Randomized controlled trial of prolonged exposure using imaginal exposure vs. virtual reality exposure in active duty soldiers with deploymentrelated posttraumatic stress disorder (PTSD). Journal of Consulting and Clinical Psychology, 84(11), 946-959. https://doi.org/10.1037/ccp0000134

**Resick, P. A., Nishith, P., Weaver, T. L., Astin, M. C., \& Feuer, C. A. (2002). A comparison of cognitive-processing therapy with prolonged exposure and a waiting condition for the 
treatment of chronic posttraumatic stress disorder in female rape victims. Journal of Consulting and Clinical Psychology, 70(4), 867-879. https://doi.org/10.1037/0022$\underline{006 X .70 .4 .867}$

*Resick, P. A., Wachen, J. S., Dondanville, K. A., Pruiksma, K. E., Yarvis, J. S., Peterson, A. L., Mintz, J., and the STRONG STAR Consortium, Borah, E. V., Brundige, A., Hembree, E. A., Litz, B. T., Roache, J. D., \& Young-McCaughan, S. (2017). Effect of group vs individual cognitive processing therapy in active-duty military seeking treatment for posttraumatic stress disorder: A randomized clinical trial. JAMA Psychiatry, 74(1), 28. https://doi.org/10.1001/jamapsychiatry.2016.2729

*Resick, P. A., Wachen, J. S., Mintz, J., Young-McCaughan, S., Roache, J. D., Borah, A. M., Borah, E. V., Dondanville, K. A., Hembree, E. A., Litz, B. T., \& Peterson, A. L. (2015). A randomized clinical trial of group cognitive processing therapy compared with group present-centered therapy for PTSD among active duty military personnel. Journal of Consulting and Clinical Psychology, 83(6), 1058-1068.

https://doi.org/10.1037/ccp0000016

Roberge, E. M., Bryan, C. J., Peterson, A., \& Rudd, M. D. (2019). Variables associated with reductions in insomnia severity among acutely suicidal patients receiving brief cognitive behavioral therapy for suicide prevention. Journal of Affective Disorders, 252, 230-236. https://doi.org/10.1016/j.jad.2019.04.045

*Roberge, E. M., Harris, J. A., Weinstein, H. R., \& Rozek, D. C. (2021). Treating Veterans at Risk for Suicide: An Examination of the Safety, Tolerability, and Outcomes of Cognitive Processing Therapy. Journal of Traumatic Stress, 0, 1-10. https://doi.org/10.1002/jts.22662 
Roberge, E. M., Leifker, F. R., Baker, S. N., Rozek, D. C., \& Bryan, C. J. (2020). Suicide following trauma. In J. G. Beck \& D. M. Sloan (Eds.), The Oxford Handbook of Traumatic Stress Disorders, Second Edition. Oxford University Press. https://doi.org/10.1093/oxfordhb/9780190088224.013.12

Ronconi, J. M., Shiner, B., \& Watts, B. V. (2014). Inclusion and exclusion criteria in randomized controlled trials of psychotherapy for PTSD. Journal of Psychiatric Practice, 20(1), 2537. https://doi.org/10.1097/01.pra.0000442936.23457.5b

Roy Rosenzweig Center for History and New Media. (2020). Zotero [Computer software]. $\underline{\text { Retrieved from www.zotero.org/download }}$

Rozek, D. C., \& Bryan, C. J. (2020). Integrating crisis response planning for suicide prevention into trauma-focused treatments: A military case example. Journal of Clinical Psychology, 76(5), 852-864. https://doi.org/10.1002/jclp.22920

Rozek, D. C., Keane, C., Sippel, L. M., Stein, J. Y., Rollo-Carlson, C., \& Bryan, C. J. (2019). Short-term effects of crisis response planning on optimism in a US Army sample. Early intervention in psychiatry, 13(3), 682-685.

*Rudd, M. D., Bryan, C. J., Wertenberger, E. G., Peterson, A. L., Young-McCaughan, S., Mintz, J., Williams, S.R., Arner, K.A., Breitbach, J., Delano, K. Wilkinson, E., \& Bruce, T. O. (2015). Brief cognitive-behavioral therapy effects on post-treatment suicide attempts in a military sample: results of a randomized clinical trial with 2-year follow-up. American journal of psychiatry, 172(5), 441-449.

Salkovskis, P. M., Atha, C., \& Storer, D. (1990). Cognitive-behavioural problem solving in the treatment of patients who repeatedly attempt suicide a controlled trial. British Journal of Psychiatry, 157(6), 871-876. https://doi.org/10.1192/bjp.157.6.871 
Shapiro, F. (2018). Eye movement desensitization and reprocessing (EDMR) therapy: Basic principles, protocols, and procedures (Third edition). The Guilford Press.

*Simon, N. M., Hoeppner, S. S., Lubin, R. E., Robinaugh, D. J., Malgaroli, M., Norman, S. B., Acierno, R., Goetter, E.M., Hellberg, S.N., Charney, M.E., Bui, E., Baker, A.W., Smith, E., Kim, H M., \& Rauch, S. A. (2020). Understanding the impact of complicated grief on combat related posttraumatic stress disorder, guilt, suicide, and functional impairment in a clinical trial of post-9/11 service members and veterans. Depression and anxiety, 37(1), $63-72$

Stanley, B., \& Brown, G. K. (2012). Safety planning intervention: A brief intervention to mitigate suicide risk. Cognitive and Behavioral Practice, 19(2), 256-264. https://doi.org/10.1016/j.cbpra.2011.01.001

Stanley, B., Brown, G. K., Brenner, L. A., Galfalvy, H. C., Currier, G. W., Knox, K. L., Chaudhury, S. R., Bush, A. L., \& Green, K. L. (2018). Comparison of the safety planning intervention with follow-up vs usual care of suicidal patients treated in the emergency department. JAMA Psychiatry, 75(9), 894. https://doi.org/10.1001/jamapsychiatry.2018.1776

Stanley, I. H., Marx, B. P., Keane, T. M., \& Vujanovic, A. A. (2021). PTSD symptoms among trauma-exposed adults admitted to inpatient psychiatry for suicide-related concerns. Journal of Psychiatric Research, 133, 60-66. https://doi.org/10.1016/j.jpsychires.2020.12.001

*Stayton, L. E., Martin, C. E., Pease, J. L., \& Chard, K. M. (2019). Changes in suicidal ideation following cognitive processing therapy in a VA residential treatment program. Military Psychology, 31(4), 326-334. https://doi.org/10.1080/08995605.2019.1630230 
*Steuwe, C., Rullkötter, N., Ertl, V., Berg, M., Neuner, F., Beblo, T., \& Driessen, M. (2016). Effectiveness and feasibility of Narrative Exposure Therapy (NET) in patients with borderline personality disorder and posttraumatic stress disorder - a pilot study. $B M C$ Psychiatry, 16(1), 254. https://doi.org/10.1186/s12888-016-0969-4

**Surís, A., Link-Malcolm, J., Chard, K., Ahn, C., \& North, C. (2013). A randomized clinical trial of cognitive processing therapy for veterans with PTSD related to military sexual trauma: Randomized trial of CPT for MST-related PTSD. Journal of Traumatic Stress, 26(1), 28-37. https://doi.org/10.1002/jts.21765

Tabares, J. V., Butner, J. E., Bryan, C. J., \& A. Harris, J. (2020). Mokken scale analysis of lifetime responses on the Columbia suicide severity rating scale's severity of ideation subscale. Assessment, 107319112091362. https://doi.org/10.1177/1073191120913626

*Tripp, J. C., Haller, M., Trim, R. S., Straus, E., Bryan, C. J., Davis, B. C., Lyons, R., Hamblen, J. L., \& Norman, S. B. (2020). Does exposure exacerbate symptoms in veterans with PTSD and alcohol use disorder? Psychological Trauma: Theory, Research, Practice, and Policy. https://doi.org/10.1037/tra0000634

**van den Berg, D. P. G., de Bont, P. A. J. M., van der Vleugel, B. M., de Roos, C., de Jongh, A., Van Minnen, A., \& van der Gaag, M. (2015). Prolonged exposure vs eye movement desensitization and reprocessing vs waiting list for posttraumatic stress disorder in patients with a psychotic disorder: A randomized clinical trial. JAMA Psychiatry, 72(3), 259. https://doi.org/10.1001/jamapsychiatry.2014.2637

*van den Berg, D. P. G., de Bont, P. A. J. M., van der Vleugel, B. M., de Roos, C., de Jongh, A., van Minnen, A., \& van der Gaag, M. (2016). Trauma-focused treatment in ptsd patients 
with psychosis: Symptom exacerbation, adverse events, and revictimization.

Schizophrenia Bulletin, 42(3), 693-702. https://doi.org/10.1093/schbul/sbv172

*van den Berg, D. P. G., \& van der Gaag, M. (2012). Treating trauma in psychosis with EMDR:

A pilot study. Journal of Behavior Therapy and Experimental Psychiatry, 43(1), 664-

671. https://doi.org/10.1016/j.jbtep.2011.09.011

**Walter, K. H., Varkovitzky, R. L., Owens, G. P., Lewis, J., \& Chard, K. M. (2014). Cognitive processing therapy for veterans with posttraumatic stress disorder: A comparison between outpatient and residential treatment. Journal of Consulting and Clinical Psychology, 82(4), 551-561. https://doi.org/10.1037/a0037075 


\begin{tabular}{ll}
\hline Database & Search Terms \\
& (Eye Movement Desensitization Reprocessing OR "trauma \\
management therapy" OR "dialectical behavior therapy" & OR "crisis response plan*" OR "suicide prevention" OR \\
& "cognitive processing therapy" OR "prolonged exposure" \\
& OR "written exposure therapy" OR crisis intervention OR \\
psychotherapy OR "trauma treatment") AND ((ptsd) OR \\
("posttraumatic stress") AND self-injurious behavior)
\end{tabular}

Applied Filters

Results

Published between 1985 - January 26, 2021; Article types selected: Case Reports, Clinical Study, Clinical Trial, Clinical Trial, Phase I, Clinical Trial, Phase II, Clinical Trial, Phase III, Clinical Trial, Phase IV, Controlled Clinical Trial, Corrected and Republished Article, Evaluation Study, Guideline, Journal Article, Meta-Analysis, Multicenter Study, Observational Study, Practice Guideline, Pragmatic Clinical Trial, Randomized Controlled Trial, Review, Systematic Review, Validation Study

Published between 1985 - January 26, 2021; Academic journals

("posttraumatic stress disorder" OR ptsd OR "post(suin "OR "self-der " postraumatic stress") AND behavior" OR "self-injur*" OR "self harm" OR parasuicid* desensitization therapy" OR "trauma management therapy" OR "written exposure therapy" OR "dialectical behavior Intervention" OR "Psychotherapy" OR "Exposure y" OR "Trauma Treatment") 
("posttraumatic stress disorder" OR ptsd OR "posttraumatic stress disorder" OR "posttraumatic stress") AND (suicid* OR "self-destructive behavior" OR "self-injurious behavior" OR "self-injur*" OR "self harm" OR parasuicid* ) AND ("cognitive therapy" OR "behavior* therapy" OR

PTSDpubs "cognitive behavior therapy" OR "cognitive processing therapy" OR "prolonged exposure" OR "eye movement desensitization therapy" OR "trauma management therapy" OR "written exposure therapy" OR "dialectical behavior therapy" OR "crisis response planning" OR "means restriction" OR "Suicide Prevention" OR "Crisis Intervention" OR "Psychotherapy" OR "Exposure Therapy" OR "Trauma Treatment")
Published between 1985 - June 23, 2021; Exclude books, book chapters, and book reviews 
Table 2. Overview of included studies and reported PTSD and suicide-related outcomes

\begin{tabular}{|c|c|c|c|c|c|c|c|c|c|c|}
\hline $\begin{array}{c}\text { Study } \\
\text { Author, } \\
\text { Year }\end{array}$ & $\begin{array}{l}\text { Population/ } \\
\text { Sample }\end{array}$ & $\begin{array}{c}\% \\
\text { Female }\end{array}$ & $\begin{array}{l}\text { Treatment } \\
\text { Format }\end{array}$ & $\begin{array}{c}\text { Treatment } \\
\text { Type }\end{array}$ & Medication & $\begin{array}{c}\text { Treatment } \\
\text { Description }\end{array}$ & $\begin{array}{c}\text { PTSD } \\
\text { Measure }\end{array}$ & $\begin{array}{c}\text { Suicide } \\
\text { Measure }\end{array}$ & $\begin{array}{l}\text { PTSD and Suicide } \\
\text { Outcomes }\end{array}$ & Quality \\
\hline \multicolumn{11}{|c|}{ Trauma-focused treatments } \\
\hline $\begin{array}{l}\text { Blain et al., } \\
2020\end{array}$ & $\begin{array}{l}107 \text { military } \\
\text { veterans with } \\
\text { PTSD ( } 98 \% \text { ) or } \\
\text { subthreshold } \\
\text { PTSD in a VA } \\
\text { residential } \\
\text { treatment } \\
\text { program. } \\
\text { Majority of } \\
\text { veterans were } \\
\text { post-Vietnam } \\
\text { and had a range } \\
\text { in trauma type } \\
\text { (e.g., combat, } \\
\text { sexual assault). }\end{array}$ & $36 \%$ & $\begin{array}{l}\text { Residential, } \\
\text { combined } \\
\text { group and } \\
\text { individual }\end{array}$ & CPT & $\begin{array}{l}\text { Not } \\
\text { reported, no } \\
\text { related } \\
\text { exclusion } \\
\text { criteria }\end{array}$ & $\begin{array}{l}12 \text { sessions over } \\
7 \text { weeks using a } \\
\text { group }(2 \mathrm{x} \\
\text { weekly for } 75 \\
\text { minutes) and } \\
\text { individual } \\
\text { protocol ( } 2 \mathrm{x} \\
\text { weekly for } 60 \\
\text { minutes; i.e., } \\
\text { Chard et al., } \\
\text { 2009). Veterans } \\
\text { were also able to } \\
\text { participate in } \\
\text { other groups } \\
\text { (e.g., } \\
\text { psychoeducation } \\
\text {, recreational) }\end{array}$ & $\begin{array}{l}\text { CAPS-5; } \\
\text { PCL-5 }\end{array}$ & BSSI & $\begin{array}{l}\text { Both PTSD and SI } \\
\text { symptoms } \\
\text { significantly } \\
\text { reduced from pre-to } \\
\text { post treatment. } \\
\text { Reductions in PTSD } \\
\text { symptoms severity } \\
\text { predicted changes } \\
\text { and suicidal } \\
\text { ideation. PTSD } \\
\text { symptom reductions } \\
\text { were indirectly } \\
\text { associated with } \\
\text { reductions in SI } \\
\text { through reductions } \\
\text { in perceived } \\
\text { burdensomeness. }\end{array}$ & Moderate \\
\hline $\begin{array}{l}\text { Bryan et al., } \\
2018\end{array}$ & $\begin{array}{l}20 \text { active-duty } \\
\text { military and } \\
\text { veterans with } \\
\text { PTSD diagnoses } \\
\text { or subthreshold } \\
\text { symptomology } \\
\text { in an ITP. The } \\
\text { majority }(70 \%) \\
\text { were post-9/11 } \\
\text { veterans and the } \\
\text { index traumas } \\
\text { reported } \\
\text { included } \\
\text { combat/deploym } \\
\text { ent-related } \\
\text { trauma (45\%), } \\
\text { sexual trauma } \\
(45 \%),\end{array}$ & $40 \%$ & $\begin{array}{l}\text { Outpatient, } \\
\text { individual }\end{array}$ & CPT & $\begin{array}{l}\text { Not } \\
\text { reported, no } \\
\text { related } \\
\text { exclusion } \\
\text { criteria }\end{array}$ & $\begin{array}{l}12 \text { sessions } \\
\text { delivered daily } \\
\text { over the course } \\
\text { of } 2 \text { weeks. } \\
\text { Treatment was } \\
\text { augmented by } \\
\text { recreational } \\
\text { activities (e.g., } \\
\text { hiking, biking, } \\
\text { skiing). }\end{array}$ & $\begin{array}{l}\text { CAPS-5; } \\
\text { PCL-5 }\end{array}$ & BSSI & $\begin{array}{l}\text { Both PTSD and SI } \\
\text { decreased } \\
\text { significantly over } \\
\text { the course of } \\
\text { treatment. } \\
\text { Specifically, } 75 \% \\
\text { experienced a } \\
\text { clinically reliable } \\
\text { clinician-rated and } \\
69 \% \text { a self-reported } \\
\text { PTSD symptom } \\
\text { reduction from pre- } \\
\text { to post-treatment. } \\
\text { Approximately } 55 \% \\
\text { of the sample } \\
\text { experience reliable } \\
\text { change in SI from } \\
\text { pre-treatment to the }\end{array}$ & Strong \\
\hline
\end{tabular}


witnessing

accidental death

(5\%), and

childhood

sexual abuse

(5\%).

\begin{tabular}{|c|c|}
\hline $\begin{array}{l}\text { Johnson et } \\
\text { al. (in press) } \\
\text { *Monson et } \\
\text { al., } 2018\end{array}$ & $\begin{array}{l}188 \text { community- } \\
\text { based active- } \\
\text { duty }(19.2 \%), \\
\text { veteran }(23.3 \%) \\
\text { and civilian } \\
(57.6 \%) \\
\text { individuals with } \\
\text { a diagnosis of } \\
\text { PTSD. Trauma } \\
\text { type was not } \\
\text { specified. }\end{array}$ \\
\hline
\end{tabular}

Resick et al., 2017

\author{
268 active-duty \\ service members \\ seeking \\ reatment for \\ PTSD after \\ deployments to \\ or near Iraq or \\ Afghanistan.
}

6-month follow-up

timepoint.

Importantly, no

suicide attempts

were reported

during treatment or

at follow-up.

PTSD and SI

reduced

significantly over

the course of

treatment.

Specifically, among

treatment

completers,

approximately $52 \%$

experienced reliable

clinically significant

improvement of

PTSD symptoms.

Individuals showing

larger decreases in

PTSD symptoms

tended to show

larger decreases in

SI relative to those

showing smaller

PTSD symptom

decreases. PTSD

symptoms predicted

SI at the subsequent

session when

controlling for the

prior session SI and

the SI symptom

trajectory.

PTSD and

$\begin{array}{ll}\begin{array}{l}\text { Stable } \\ \text { psychotropic }\end{array} & \begin{array}{l}\text { Individual CPT } \\ (n=135) \text { was }\end{array} \\ \text { medication } & \text { delivered in 60- } \\ \text { regimen } & \text { minute sessions } \\ \text { required. } & 2 \times / \text { week for 6 } \\ 57.1 \% \text { on } & \text { weeks, and } \\ \text { current } & \text { group CPT ( } n= \\ & \text { 133) was }\end{array}$

PCL-S; BSSI

suicidality reduced

significantly over

the course of

treatment.

Individuals who

received individual

treatment improved
Strong

Moderate 
The sample endorsed a range of

different

traumatic events

including

combat-related

trauma, non-

combat-related

death, and

sexual assault.

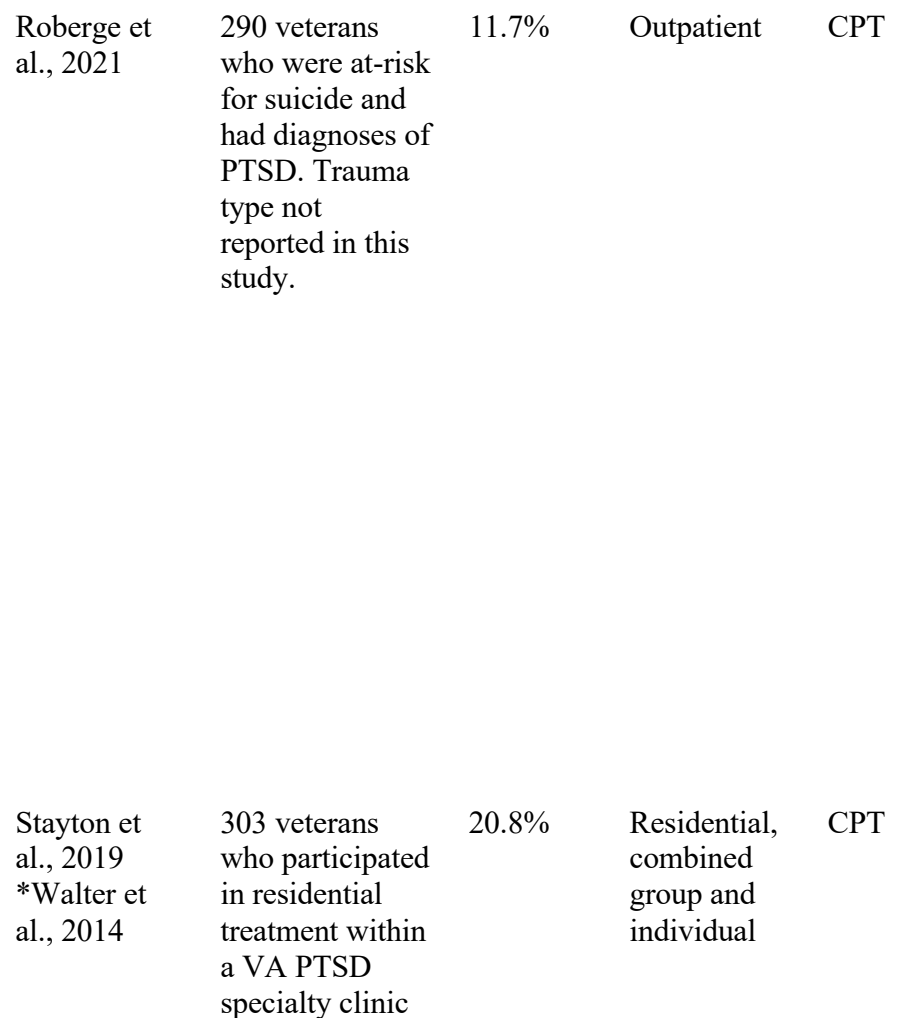

specialty clinic psychotropic medications.

delivered in 90minute sessions

$2 \mathrm{x} /$ week for 6

weeks.

$\begin{array}{ll}\text { Not } & \text { Delivered in a } \\ \text { reported, no } & \text { standard } \\ \text { related } & \text { outpatient } \\ \text { exclusion } & \text { treatment } \\ \text { criteria } & \text { program at a VA } \\ & \text { clinic. }\end{array}$

Not

related

exclusion

criteria

format with $2 \mathrm{x}$

75-min group

sessions in addition to $2 \mathrm{x}$

50-min to a greater extent

and more rapidly

than those who

received group

treatment but

overall effects

between conditions

were small and non-

significant. There

were no differences

condition for rates

of patients no longer

meeting the

diagnostic criteria

for PTSD.

PTSD significantly Weak

behaviors reduced over the

(suicide course of treatment.

attempts) Suicide risk did not

measured impact or predict

by chart participants abilities

review. to complete $\mathrm{CPT}$,

Two nor did it predict

contrast variability in

coding participants'

approache treatment response

s used to or rate of symptom

categorize reduction. Two

suicide participants

risk level. attempted suicide

about seven months

post treatment, and

one attempted

suicide about one

month after the first

and only treatment

session.

PHQ-9
item 9

PTSD and SI

Weak

significantly

reduced over the

course of treatment

This change did not

differ based on age, 
between July

2014 and

September

2017. Veterans

were admitted to

a men's $(n=81)$,

women's ( $n=$

$63)$, or men's

PTSD/TBI $(n=$

159) program at

a Midwestern

United States

VA Medical

Center. Trauma

type was not

specified.

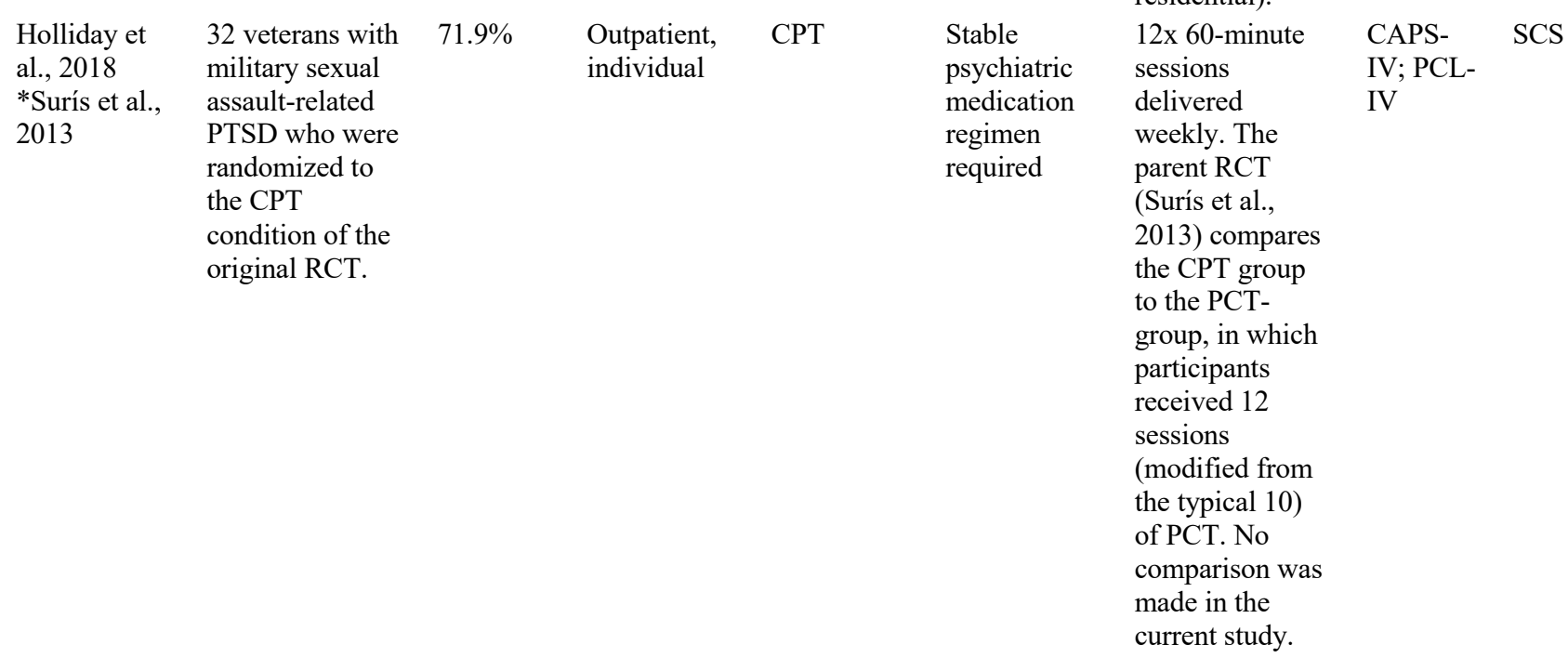

individual

sessions per

week. Veterans

also participated

in

psychoeducation

al group

programming

and groups and

events such as

gardening and

knitting to

promote social

interaction. No

comparison

group was

included (parent

study examined

outpatient vs.

residential)

PTSD and suicide

Moderate

cognitions

significantly

reduced over the

course of treatment.

Symptom

reductions were

moderate to large. marital status, sex, or race/ethnicity. 


\begin{tabular}{|c|c|c|c|c|c|c|c|c|c|c|}
\hline $\begin{array}{l}\text { Horwitz et } \\
\text { al., } 2018\end{array}$ & $\begin{array}{l}177 \text { military } \\
\text { members and } \\
\text { veterans in an } \\
\text { ITP for PTSD. } \\
\text { Trauma type not } \\
\text { reported. }\end{array}$ & $34 \%$ & $\begin{array}{l}\text { Outpatient, } \\
\text { combined } \\
\text { group and } \\
\text { individual }\end{array}$ & $\mathrm{CPT}$ & $\begin{array}{l}\text { Not } \\
\text { reported, no } \\
\text { related } \\
\text { exclusion } \\
\text { criteria }\end{array}$ & $\begin{array}{l}\text { Group (12 } \\
\text { sessions) and } \\
\text { individual (15 } \\
\text { sessions) } \\
\text { delivered over } 3 \\
\text { weeks. } \\
\text { Treatment was } \\
\text { augmented with } \\
\text { mindfulness- } \\
\text { based classes } \\
\text { (13 sessions), } \\
\text { yoga (12 } \\
\text { classes), and } \\
\text { other various } \\
\text { educational and } \\
\text { skills-based } \\
\text { classes. }\end{array}$ & PCL-5 & $\begin{array}{l}\text { PHQ-9 } \\
\text { item } 9\end{array}$ & $\begin{array}{l}\text { PTSD and SI } \\
\text { reduced } \\
\text { significantly over } \\
\text { the course of } \\
\text { treatment. Study } \\
\text { results also showed } \\
\text { that PTSD } \\
\text { symptoms were not } \\
\text { uniquely associated } \\
\text { with SI, while pre- } \\
\text { treatment SI was } \\
\text { significantly } \\
\text { associated with post } \\
\text { treatment SI. }\end{array}$ & Weak \\
\hline $\begin{array}{l}\text { Cigrang et } \\
\text { al., } 2011\end{array}$ & $\begin{array}{l}15 \text { active-duty } \\
\text { or activated } \\
\text { reserve } \\
\text { OEF/OIF } \\
\text { veterans with } \\
\text { PTSD who } \\
\text { agreed to } \\
\text { participate in a } \\
\text { primary care- } \\
\text { based treatment } \\
\text { protocol. } \\
\text { Trauma history } \\
\text { included } \\
\text { combat-related } \\
\text { events such as } \\
\text { being in a } \\
\text { vehicle under } \\
\text { fire, seeing dead } \\
\text { bodies, and } \\
\text { going on combat } \\
\text { patrols or } \\
\text { missions. }\end{array}$ & $20 \%$ & $\begin{array}{l}\text { Outpatient, } \\
\text { individual }\end{array}$ & $\begin{array}{l}\text { Manualized } \\
\text { primary } \\
\text { care-based } \\
\text { interventio } \\
n \text { based on } \\
\text { emotional } \\
\text { processing } \\
\text { theory and } \\
\text { the PE } \\
\text { model and } \\
\text { drawing } \\
\text { content } \\
\text { from CBT } \\
\text { for PTSD }\end{array}$ & $\begin{array}{l}40 \% \text { of } \\
\text { participants } \\
\text { were taking } \\
\text { at least one } \\
\text { medication, } \\
\text { including } \\
\text { bupropion, } \\
\text { citalopram, } \\
\text { lorazepam, } \\
\text { quetiapine, } \\
\text { Risperdal, } \\
\text { and } \\
\text { zolpidem. }\end{array}$ & $\begin{array}{l}\text { 4-6x 30-minute } \\
\text { appointments. } \\
\text { Treatment was } \\
\text { delivered by a } \\
\text { psychologist in } \\
\text { primary care. } \\
\text { Sessions } 5 \text { and } 6 \\
\text { were optional, } \\
\text { and homework } \\
\text { was assigned for } \\
\text { completion } \\
\text { between } \\
\text { assignments. No } \\
\text { comparison } \\
\text { group was } \\
\text { included. }\end{array}$ & $\begin{array}{l}\text { PSS-I; } \\
\text { PCL-M }\end{array}$ & BSSI & $\begin{array}{l}\text { PTSD symptoms } \\
\text { significantly } \\
\text { reduced over the } \\
\text { course of treatment. } \\
\text { Specifically, } 50 \% \text { of } \\
\text { treatment } \\
\text { completers no } \\
\text { longer met criteria } \\
\text { for PTSD at 1- } \\
\text { month follow up. } \\
\text { Importantly, there } \\
\text { were no reports of } \\
\text { suicidal thoughts, } \\
\text { behaviors, or plans } \\
\text { from any study } \\
\text { participants at either } \\
\text { pre-treatment or } \\
\text { follow-up. }\end{array}$ & Strong \\
\hline
\end{tabular}




\begin{tabular}{|c|c|c|c|c|c|c|c|c|c|c|}
\hline $\begin{array}{l}\text { Gradus et al., } \\
2013 \\
\text { *Resick et } \\
\text { al., } 2002\end{array}$ & $\begin{array}{l}163 \text { adult } \\
\text { women who had } \\
\text { experienced } \\
\text { rape. The } \\
\text { participants } \\
\text { experienced } 6.4 \\
\text { lifetime crime } \\
\text { incidents (e.g., } \\
\text { child sexual or } \\
\text { physical abuse, } \\
\text { robbery, } \\
\text { interpersonal } \\
\text { violence, rape, } \\
\text { and assault) in } \\
\text { addition to the } \\
\text { index rape, on } \\
\text { average. }\end{array}$ & $100 \%$ & $\begin{array}{l}\text { Outpatient, } \\
\text { individual }\end{array}$ & $\begin{array}{l}\text { PE }(n=84) \\
\text { or CPT+A } \\
(n=79)\end{array}$ & $\begin{array}{l}\text { Stable } \\
\text { psychotropic } \\
\text { medication } \\
\text { regimen } \\
\text { required. } \\
30.7 \% \text { of } \\
\text { parent trial } \\
\text { sample on } \\
\text { current } \\
\text { psychotropic } \\
\text { medications. }\end{array}$ & $\begin{array}{l}\text { Participants } \\
\text { were } \\
\text { randomized in a } \\
\text { parent trial and } \\
\text { received PE, } \\
\text { CPT+A for } \\
\text { PTSD, or WL } \\
\text { (not used in this } \\
\text { study). CPT and } \\
\text { PE were } \\
\text { delivered } \\
\text { according to } \\
\text { standard } \\
\text { protocols and } \\
\text { sessions were } 2 x \\
\text { weekly over } 6 \\
\text { weeks. }\end{array}$ & PSS & $\begin{array}{l}\text { BDI item } \\
9\end{array}$ & $\begin{array}{l}\text { PTSD and SI } \\
\text { decreased } \\
\text { throughout } \\
\text { treatment. There } \\
\text { were sharp declines } \\
\text { in PTSD symptoms } \\
\text { that leveled over } \\
\text { time with no } \\
\text { significant } \\
\text { differences between } \\
\text { groups. } \\
\text { Additionally, there } \\
\text { were sharp } \\
\text { decreases in SI } \\
\text { during treatment } \\
\text { that continued to } \\
\text { decrease during } \\
\text { follow-up, albeit at } \\
\text { a slower rate. } \\
\text { Declines in SI } \\
\text { appeared greater for } \\
\text { those receiving } \\
\text { CPT. }\end{array}$ & Moderate \\
\hline $\begin{array}{l}\text { Post et al. (in } \\
\text { press) }\end{array}$ & $\begin{array}{l}684 \text { veterans } \\
\text { and military } \\
\text { members at two } \\
\text { ITPs for PTSD. } \\
\text { The majority of } \\
\text { participants } \\
\text { served post } 9 / 11 \\
\text { and were } \\
\text { discharged or } \\
\text { retired at the } \\
\text { time of the } \\
\text { study. Trauma } \\
\text { type was not } \\
\text { reported. }\end{array}$ & $32.31 \%$ & $\begin{array}{l}\text { Outpatient, } \\
\text { combined } \\
\text { group and } \\
\text { individual }\end{array}$ & $\begin{array}{l}\text { PE }(n=376) \\
\text { or CPT } \\
(n=308)\end{array}$ & $\begin{array}{l}\text { Not } \\
\text { reported, no } \\
\text { related } \\
\text { exclusion } \\
\text { criteria }\end{array}$ & $\begin{array}{l}\text { PE was } \\
\text { delivered in a 2- } \\
\text { week ITP format } \\
\text { with individual } \\
\text { 90-minute } \\
\text { sessions daily ( } 9 \\
\text { total) and group } \\
120 \text {-minute } \\
\text { sessions ( } 9 \text { total) } \\
\text { in vivo } \\
\text { exposure. } \\
\text { Augmentation in } \\
\text { the PE treatment } \\
\text { included a } \\
\text { variety of other } \\
\text { services and } \\
\text { classes (e.g., } \\
\text { medication } \\
\text { management, } \\
\text { career/financial } \\
\text { support, yoga, }\end{array}$ & PCL-5 & $\begin{array}{l}\text { PHQ-9 } \\
\text { item } 9\end{array}$ & $\begin{array}{l}\text { PTSD and SI reduce } \\
\text { significantly over } \\
\text { the course of } \\
\text { treatment. } \\
\text { Specifically, PTSD } \\
\text { symptom reductions } \\
\text { were large, whereas } \\
\text { SI reductions were } \\
\text { small. The average } \\
\text { amount of change in } \\
\text { PTSD and SI } \\
\text { symptoms } \\
\text { throughout } \\
\text { treatment was } \\
\text { similar across both } \\
\text { groups. In both } \\
\text { groups, reductions } \\
\text { and PTSD severity } \\
\text { predicted } \\
\text { subsequent } \\
\text { reductions in SI. }\end{array}$ & Moderate \\
\hline
\end{tabular}




\begin{tabular}{|c|c|c|c|}
\hline $\begin{array}{l}\text { Simon et al., } \\
2020 \\
\text { * Rauch et } \\
\text { al., } 2018 \mathrm{a} \text {, } \\
\text { Rauch et al., } \\
2018 \text { b }\end{array}$ & $\begin{array}{l}223 \text { veterans or } \\
\text { service members } \\
\text { of the United } \\
\text { States military } \\
\text { with a primary } \\
\text { diagnosis of } \\
\text { combat-related } \\
\text { PTSD who } \\
\text { served in the } \\
\text { Iraq/Afghanista } \\
\text { n wars. The } \\
\text { sample } \\
\text { consisted of } \\
\text { those with and } \\
\text { those without } \\
\text { complicated } \\
\text { grief. } \\
\text { Participants had } \\
\text { combat-related } \\
\text { traumas. }\end{array}$ & $\begin{array}{l}\text { With } \\
\text { complica } \\
\text { ted grief: } \\
11 \% \\
\text { Without } \\
\text { complica } \\
\text { ted grief: } \\
13 \%\end{array}$ & $\begin{array}{l}\text { Outpatient, } \\
\text { individual }\end{array}$ \\
\hline
\end{tabular}

etc.). CPT was

delivered in a 3-

week ITP with

individual 50-

minute sessions

daily (14 total)

and group 120

minute sessions

daily (13 total).

Augmentation in

the CPT

treatment

included daily

mindfulness and

yoga, as well as

a variety of

other services

(e.g.,

psychoeducation

groups, skills

coaching).

Sertraline or Participants

placebo. received either

Participants PE for PTSD

taking and a placebo

concurrent pill, PE and

antidepressa sertraline, or

nts or

sertraline and

antipsychoti enhanced

cs were medication

excluded. management.

Benzodiazep Analyses

ines,

included 194
participants.

prazo

and sleep Participants

agents (e.g., completed 13

Zolpidem) weeks of their

allowed if randomly

dose was assigned

stable for at treatment

least 2 followed by 12

weeks. additional weeks

of pill
continuation and

of pill
continuation and
CAPS- C-SSRS PTSD symptoms

significantly

reduced through all

conditions, with no

significant

differences between

the groups. In a

secondary analysis

examining

complicated grief

(CG), participants

were analyzed in 2

groups (those with

vs. those without

CG). Among both

groups, suicidal

behavior during

treatment was rare

(3\%) and PTSD

symptoms

significantly

reduced. There were

no between-group
Weak

n




\begin{tabular}{|c|c|c|c|c|c|c|c|c|c|c|}
\hline & & & & & & $\begin{array}{l}\text { completion of } \\
\text { missed sessions } \\
\text { for PE. PE was } \\
\text { delivered in up } \\
\text { to } 1390 \text {-minute } \\
\text { sessions. }\end{array}$ & & & $\begin{array}{l}\text { differences. Further, } \\
\text { participants with } \\
\text { CG were more } \\
\text { likely to experience } \\
\text { some level of SI } \\
\text { during the study, but } \\
\text { there were no } \\
\text { differences in the } \\
\text { odds of } \\
\text { experiencing worse } \\
\text { SI during the } \\
\text { treatment period } \\
\text { relative to the } \\
\text { month before } \\
\text { treatment. }\end{array}$ & \\
\hline $\begin{array}{l}\text { Brown et al., } \\
2019 \\
\text { *Foa et al., } \\
2018\end{array}$ & $\begin{array}{l}335 \text { military } \\
\text { personnel who } \\
\text { met criteria for } \\
\text { PTSD and were } \\
\text { exposed to } \\
\text { combat-related } \\
\text { trauma. }\end{array}$ & $10.7 \%$ & $\begin{array}{l}\text { Outpatient, } \\
\text { individual }\end{array}$ & PE & $\begin{array}{l}\text { No related } \\
\text { exclusion } \\
\text { criteria. In } \\
\text { parent trial, } \\
54.5 \% \text { of } \\
\text { participants } \\
\text { in M-PE, } \\
58.7 \% \text { in S- } \\
\text { PE, } 51.4 \% \text { in } \\
\text { PCT, and } \\
70 \% \text { in } \\
\text { MCC were } \\
\text { not taking } \\
\text { psychotropic } \\
\text { medications }\end{array}$ & $\begin{array}{l}\text { Participants } \\
\text { were } \\
\text { randomized to } \\
\text { either minimal } \\
\text { contact control } \\
\text { (MCC; } n=40 ; \\
\text { weekly therapist } \\
\text { phone calls } \\
\text { lasting } 15 \\
\text { minutes for } 4 \\
\text { weeks), massed } \\
\text { PE (M-PE; } \\
n=75 ; 10 \\
\text { sessions over } 2 \\
\text { weeks), spaced } \\
\text { PE (S-PE; } \\
n=109 ; 10 \\
\text { sessions over } 8 \\
\text { weeks), or PCT } \\
(n=107 ; 10 \\
\text { sessions over } 8 \\
\text { weeks). }\end{array}$ & $\begin{array}{l}\text { PSS-I; } \\
\text { PCL-S }\end{array}$ & $\begin{array}{l}\text { BSS; } \\
\text { BDI-II } \\
\text { item 9; C- } \\
\text { SSRS } \\
\text { suicide } \\
\text { behavior } \\
\text { item }\end{array}$ & $\begin{array}{l}\text { PTSD and SI } \\
\text { symptoms } \\
\text { significantly } \\
\text { reduced over the } \\
\text { course of treatment. } \\
\text { Of individuals who } \\
\text { received spaced PE } \\
\text { and PCT, } \\
\text { approximately } 76 \% \\
\text { experienced reliable } \\
\text { improvement in } \\
\text { suicidal ideation. } \\
\text { Specifically, } \\
\text { reductions in PTSD } \\
\text { symptom severity } \\
\text { were associated } \\
\text { with reductions in } \\
\text { suicidal ideation. } \\
\text { Increased suicidal } \\
\text { ideation was } \\
\text { reported at follow- } \\
\text { up timepoints. }\end{array}$ & Moderate \\
\hline $\begin{array}{l}\text { Cox et al., } \\
2016\end{array}$ & $\begin{array}{l}289 \text { veterans } \\
\text { seeking } \\
\text { treatment for } \\
\text { PTSD at three } \\
\text { specialty care } \\
\text { VA treatment } \\
\text { facilities. }\end{array}$ & $11 \%$ & $\begin{array}{l}\text { Outpatient, } \\
\text { individual }\end{array}$ & $\mathrm{PE}$ & $\begin{array}{l}\text { Not } \\
\text { reported, no } \\
\text { related } \\
\text { exclusion } \\
\text { criteria }\end{array}$ & $\begin{array}{l}\text { Between 8-13 } \\
\text { weekly 90- } \\
\text { minute sessions. }\end{array}$ & PCL-M & $\begin{array}{l}\text { BDI-II } \\
\text { item } 9\end{array}$ & $\begin{array}{l}\text { PTSD and SI } \\
\text { significantly } \\
\text { reduced over the } \\
\text { course of treatment. } \\
\text { PTSD and SI or } \\
\text { correlated at each } \\
\text { measurement time }\end{array}$ & Weak \\
\hline
\end{tabular}


Trauma type not specified.

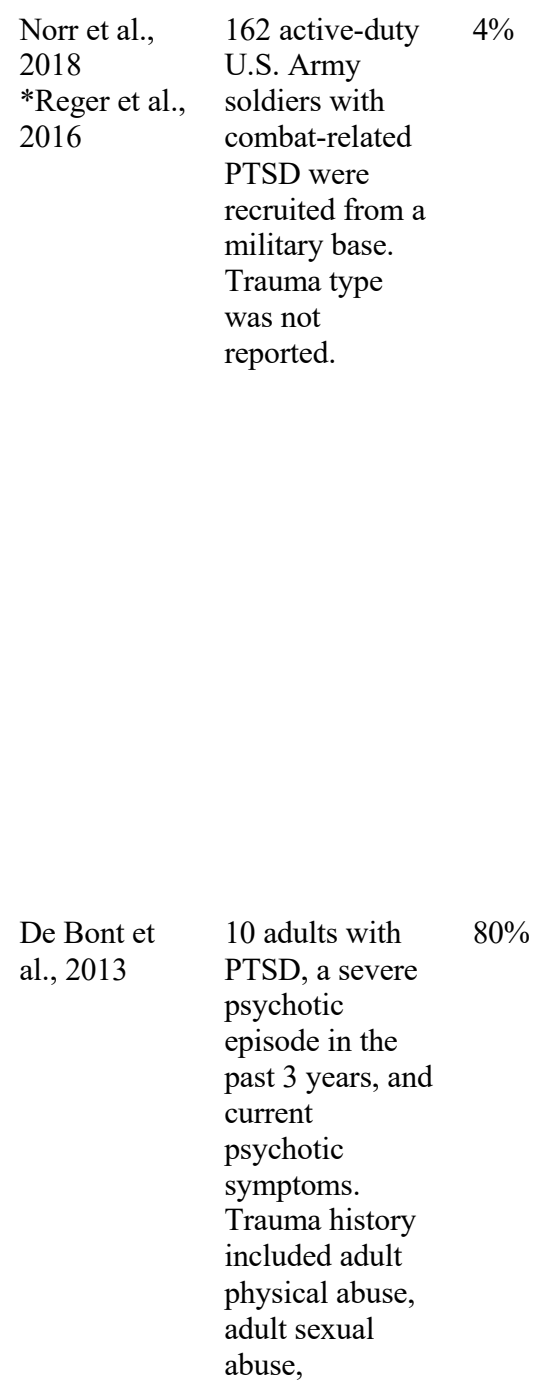

point. Previous

session PTSD

scores were

predictive of SI over

and above previous

session SI.

PTSD and SI

significantly

decreased over the

course of treatment.

The presence of SI

at baseline did not

affect PTSD

symptoms change.

Whereas reduced SI

for the treatment

groups persisted at

post-treatment,

individuals in the

waitlist condition

exhibited a slight

increase in SI.

\section{Moderate}

$\begin{array}{ll}\text { Outpatient, } & \text { PE }(n=5) \text { or } \\ \text { individual } & \begin{array}{l}\text { EMDR } \\ (n=5)\end{array}\end{array}$

treatment.

$44 \%$ of

participants

antidepressa

nts, $24 \%$ on

benzodiazepi

nes, and

$46 \%$ on

other

medications

No related

exclusion

criteria.

TAU

included

medication

for all

participants.
Up to $12 \times 90-$

minute sessions.

Both protocols

used Dutch-

translation.

xposures were

onducted using

irtual reality in

\section{PSS-SR;}

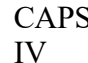

IV

Clinically adverse

(e.g.,

suicidal
behaviors)
PTSD symptoms

reduced over the course of treatment

PTSD symptom reductions were large and maintained at

follow-up.

Importantly, there were no clinically adverse events

including hospital admissions, suicidal 
childhood

bullying, child

emotional

abuse, child

physical abuse,

child sexual

abuse, violence,

and war.

van den Berg

$\&$ van der

Gaag, 2012

27 patients

outpatient

mental health

services in the

Netherlands

with

schizophrenia

spectrum

disorder and

PTSD related to

sexual abuse,

physical abuse

or physical

threatening,

emotional

abuse,

experiences

during

psychosis/treatm

ent, or other

causes (e.g.,

accidents or

war).

Jamshidi et 30 female

al., $2020 \quad$ victims of child

abuse living in

the Welfare

Organization

Center of

Shiraz, Iran

participated in

the study. All

participants

experienced

childhood abuse

including sexua behavior, or NSSI

that occurred during

treatment.

Outpatient, EMDR

No related

exclusion

criteria. 25

participants

were taking

antipsychoti

cs, 8 were

taking

antidepressa

nts, 3 were

taking

lithium, and

10 were

taking

benzodiazep

nes

Dutch version
used (De Jongh
\& Ten Broeke,
2003).

\section{CAPS- Adverse}

IV; PSS- events

(e.g.,

PTSD symptoms

significantly

Strong

suicidal large. Importantly,

ideation); there were 0 suicide

patient attempts and 0

was asked reports of NSSI.

if they

thought

any given

event was

related to

the

treatment

Participants

excluded if

taking

Participants

were

CMS

randomized to

medication either EMDR

for a

$(n=15)$ or

condition waitlist control

other than $\quad(n=15)$. EMDR

PTSD.

consisted of 3

months,

$2 \mathrm{x} /$ week, during

eight 90-minute

sessions.

Modifications
PTSD and SI

significantly

decreased for

individuals who

received treatment. 
abuse, physical abuse,

emotional

abuse, and/or

neglect.

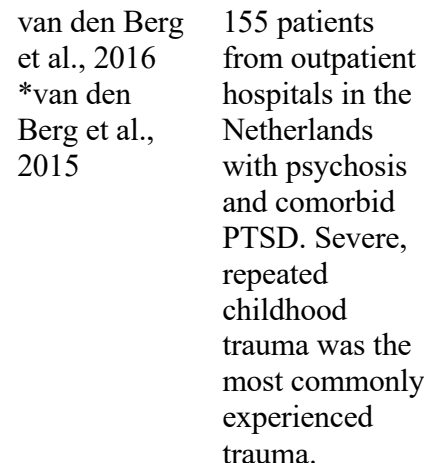

were made as

needed fo

individual

participants,

including

minimal focus

on early traumas

for those who

had significant

current

problems and

using affect

regulation

techniques.

$\begin{array}{lll}54.2 \% & \begin{array}{l}\text { Outpatient, } \\ \text { individual }\end{array} & \text { PE or } \\ & \text { EMDR }\end{array}$

Participants

were

$8 \mathrm{x}$ weekly 90

minute session

of trauma-

they had a

focused

change in

antipsychoti

$\mathrm{c}$ or

treatment for

PTSD over 10

weeks and

antidepressa

$\mathrm{nt}$

treatment-as-

usual for

medications psychosis.

within the Comparison

past two group was a

months.

condition.

Moderate

significantly

$\begin{array}{ll}10 \text { scale at } & \text { reduced over the } \\ \text { the } & \text { course of treatment. }\end{array}$

beginning SI decreased as

and end of early as the first

the first 2 session. Compared

trauma- to the waitlist

focused condition,

sessions; participants

adverse receiving trauma

events focused treatments

(e.g., experienced less

suicide PTSD symptom

attempts) exacerbation

throughout

treatment. The

following adverse

events were

reported during

treatment (TF vs

WL): self-harm

$15.4 \%$ vs. $10.3 \%$;

suicide attempt

$2.2 \%$ vs. $2.6 \%$;

crisis contact with

mental health care

$24.2 \%$ vs. $28.2 \%$

psychiatric

hospitalization $2.2 \%$ 


\begin{tabular}{|c|c|c|c|c|c|c|c|c|c|}
\hline & & & & & & & & & vs. $10.3 \%$. \\
\hline $\begin{array}{l}\text { Bryan et al., } \\
2016 \\
\text { Resick et al., } \\
2015\end{array}$ & $\begin{array}{l}108 \text { PTSD } \\
\text { treatment- } \\
\text { seeking active- } \\
\text { duty soldiers in } \\
\text { the U.S. Army. } \\
\text { The majority of } \\
\text { participants had } \\
\text { deployment- } \\
\text { related trauma. } \\
\text { Reported index } \\
\text { traumas } \\
\text { included } \\
\text { aftermath of } \\
\text { battle, traumatic } \\
\text { loss, moral } \\
\text { injury, and } \\
\text { childhood } \\
\text { sexual abuse. }\end{array}$ & $8 \%$ & $\begin{array}{l}\text { Outpatient, } \\
\text { group }\end{array}$ & $\begin{array}{l}\text { CPT } \\
(n=56) \text { or } \\
\text { PCT } \\
(n=52)\end{array}$ & $\begin{array}{l}\text { Stable } \\
\text { psychotropic } \\
\text { medication } \\
\text { regimen } \\
\text { required. }\end{array}$ & $\begin{array}{l}12 \text { sessions. All } \\
\text { treatment groups } \\
\text { were } 90 \text { minutes } \\
\text { and twice per } \\
\text { week with } \\
\text { between } 8-10 \\
\text { group members. }\end{array}$ & $\begin{array}{l}\text { PCL-S; } \\
\text { PSS-I }\end{array}$ & $\begin{array}{l}\text { Adverse } \\
\text { events } \\
\text { (both } \\
\text { study- } \\
\text { related } \\
\text { and - } \\
\text { unrelated) } \\
\text {; BSSI; } \\
\text { suicide } \\
\text { attempts } \\
\text { (triangulat } \\
\text { ed from } \\
\text { C-SSRS, } \\
\text { BSS, and } \\
\text { adverse } \\
\text { events } \\
\text { forms) }\end{array}$ & $\begin{array}{l}\text { PTSD and SI } \\
\text { significantly } \\
\text { reduced over the } \\
\text { course of treatment. } \\
\text { Specifically, PTSD } \\
\text { symptom reductions } \\
\text { were large. } \\
\text { Exacerbation of pre- } \\
\text { existing SI was } \\
\text { uncommon. } \\
\text { Importantly, there } \\
\text { were no deaths by } \\
\text { suicide in either of } \\
\text { the groups. } \\
\text { However, the were } \\
4 \text { reports of non- } \\
\text { study related SI } \\
\text { during treatment (1 } \\
\text { CPT, } 3 \text { PCT), } 3 \\
\text { non-study-related } \\
\text { reports of SI during } \\
\text { follow-up (1CPT, } 2 \\
\text { PCT), and } 1 \text { report } \\
\text { of a non-study- } \\
\text { related suicide } \\
\text { attempt a follow up } \\
\text { (CPT). }\end{array}$ \\
\hline
\end{tabular}




\begin{tabular}{|c|c|c|c|c|c|c|c|c|c|c|}
\hline $\begin{array}{l}\text { Steuwe et } \\
\text { al., } 2016\end{array}$ & $\begin{array}{l}11 \text { individuals in } \\
\text { Germany with } \\
\text { BPD and PTSD } \\
\text { without previous } \\
\text { stabilization } \\
\text { periods or the } \\
\text { absence of } \\
\text { intentional self- } \\
\text { injury. The } \\
\text { sample reported } \\
\text { an average of } \\
4.9 \text { different } \\
\text { types of lifetime } \\
\text { traumas. }\end{array}$ & $90.9 \%$ & $\begin{array}{l}\text { Inpatient, } \\
\text { individual }\end{array}$ & NET & $\begin{array}{l}\text { Stable } \\
\text { psychiatric } \\
\text { medication } \\
\text { regimen } \\
\text { required. } \\
\text { Standard } \\
\text { inpatient } \\
\text { care } \\
\text { involved } \\
\text { psychophar } \\
\text { macological } \\
\text { care not } \\
\text { including } \\
\text { benzodiazepi } \\
\text { nes as } \\
\text { needed. }\end{array}$ & $\begin{array}{l}\text { NET (17 } \\
\text { sessions) and } \\
\text { standard } \\
\text { inpatient care } \\
\text { and were } \\
\text { combined } \\
\text { during a ten- } \\
\text { week stay ( } n= \\
11) \text {. As part of } \\
\text { standard } \\
\text { inpatient care, } \\
\text { individuals also } \\
\text { received weekly } \\
\text { individual } \\
\text { custodial } \\
\text { supportive } \\
\text { sessions, twice } \\
\text { weekly art or } \\
\text { music therapy, } \\
\text { weekly body } \\
\text { therapy, } \\
\text { movement } \\
\text { therapy, and } \\
\text { psychopharmaco } \\
\text { logical treatment } \\
\text { as needed. }\end{array}$ & PDS & $\begin{array}{l}\text { Diary card } \\
\text { to rate } \\
\text { urges to } \\
\text { commit } \\
\text { suicide } \\
\text { and NSSI } \\
\text { (range 0- } \\
\text { 5) every } \\
\text { evening; } \\
\text { observatio } \\
\text { ns of } \\
\text { suicide } \\
\text { attempts } \\
\text { and NSSI } \\
\text { during the } \\
\text { NET } \\
\text { protocol }\end{array}$ & $\begin{array}{l}\text { PTSD symptoms } \\
\text { significantly } \\
\text { reduced over the } \\
\text { course of treatment } \\
\text { and remained stable } \\
\text { until 12-month } \\
\text { follow-up. } \\
\text { Approximately } 37 \% \\
\text { of study participants } \\
\text { experienced a } \\
\text { remission and PTSD } \\
\text { symptoms. Two of } \\
\text { the study } \\
\text { participants engaged } \\
\text { in NSSI but no } \\
\text { participant } \\
\text { attempted suicide. } \\
\text { At the 12-month } \\
\text { follow-up, one } \\
\text { patient reported a } \\
\text { suicide attempt, and } \\
\text { two had engaged in } \\
\text { NSSI. The average } \\
\text { intensity and pattern } \\
\text { of change in urges } \\
\text { to self-harm did not } \\
\text { significantly differ } \\
\text { between the } \\
\text { exposure and non- } \\
\text { exposure phases of } \\
\text { treatment. }\end{array}$ & Moderate \\
\hline
\end{tabular}




\begin{tabular}{|c|c|c|c|c|c|c|c|c|c|}
\hline $\begin{array}{l}\text { Persson et } \\
\text { al., } 2017\end{array}$ & $\begin{array}{l}22 \text { females with } \\
\text { both PTSD and } \\
\text { alcohol } \\
\text { dependence } \\
\text { (AD) diagnoses. } \\
\text { Index traumas } \\
\text { were mixed and } \\
\text { included } \\
\text { physical or } \\
\text { sexual assault, } \\
\text { witnessed injury } \\
\text { or death, } \\
\text { accident or } \\
\text { disaster, or } \\
\text { other. }\end{array}$ & $100 \%$ & $\begin{array}{l}\text { Outpatient, } \\
\text { individual }\end{array}$ & COPE & $\begin{array}{l}\text { Not } \\
\text { reported, no } \\
\text { related } \\
\text { exclusion } \\
\text { criteria }\end{array}$ & $\begin{array}{l}\text { Twelve 90- } \\
\text { minute weekly } \\
\text { sessions. } \\
\text { Accommodation } \\
\text { s were made for } \\
\text { missed sessions, } \\
\text { and all study } \\
\text { participants took } \\
\text { longer than the } \\
\text { scheduled } 12 \\
\text { weeks to } \\
\text { complete } \\
\text { treatment. } \\
\text { Additionally, } \\
\text { participants } \\
\text { were free to } \\
\text { access other } \\
\text { psychiatric and } \\
\text { SUD treatment } \\
\text { during the study } \\
\text { period. }\end{array}$ & $\begin{array}{l}\text { CAPS- } \\
\text { DX; } \\
\text { PCL-C }\end{array}$ & $\begin{array}{l}\text { Adverse } \\
\text { events, } \\
\text { defined as } \\
\text { increased } \\
\text { suicidality } \\
\text { as } \\
\text { measured } \\
\text { by the } \\
\text { suicidality } \\
\text { section of } \\
\text { the MINI }\end{array}$ & $\begin{array}{l}\text { PTSD symptoms } \\
\text { significantly } \\
\text { reduced over the } \\
\text { course of treatment, } \\
\text { and more than half } \\
(66.7 \%) \text { of the } \\
\text { sample no longer } \\
\text { met criteria for } \\
\text { PTSD when } \\
\text { followed up with } \\
\text { one week after the } \\
\text { end of the study. } \\
\text { There were no } \\
\text { reports of adverse } \\
\text { events (e.g., } \\
\text { increased } \\
\text { suicidality) during } \\
\text { or after treatment. }\end{array}$ \\
\hline
\end{tabular}




\begin{tabular}{|c|c|c|c|c|c|c|c|c|c|c|}
\hline $\begin{array}{l}\text { Tripp et al., } \\
2020 \\
\text { *Norman et } \\
\text { al., } 2019 \text {, } \\
\text { Norman et } \\
\text { al., } 2015\end{array}$ & $\begin{array}{l}81 \text { veterans with } \\
\text { PTSD and } \\
\text { AUD, recruited } \\
\text { from a VA } \\
\text { hospital. } \\
\text { Participants } \\
\text { experienced an } \\
\text { average of } 8.18 \\
\text { prior traumas. } \\
\text { Trauma type not } \\
\text { specified. }\end{array}$ & $14.8 \%$ & $\begin{array}{l}\text { Outpatient, } \\
\text { individual }\end{array}$ & $\begin{array}{l}\text { COPE or } \\
\text { SS }\end{array}$ & $\begin{array}{l}\text { No related } \\
\text { exclusion } \\
\text { criteria. } \\
\text { Psychiatrists } \\
\text { prescribed } \\
\text { medication } \\
\text { at study site } \\
\text { in open-label } \\
\text { format. }\end{array}$ & $\begin{array}{l}\text { Participants } \\
\text { were } \\
\text { randomized to } \\
12-16 \text { sessions } \\
\text { of } 90 \text {-minute } \\
\text { COPE or } \\
\text { Seeking Safety } \\
\text { (SS) once or } \\
\text { twice weekly } \\
\text { (see primary } \\
\text { outcome study } \\
\text { Norman et al., } \\
\text { 2019). SS was } \\
\text { modified to } \\
\text { include } 90- \\
\text { minute rather } \\
\text { than the } \\
\text { standard } 45-60- \\
\text { minute sessions. }\end{array}$ & $\begin{array}{l}\text { PCL-5; } \\
\text { CAPS-5 }\end{array}$ & $\begin{array}{l}\text { PHQ-9 } \\
\text { item } 9\end{array}$ & $\begin{array}{l}\text { PTSD symptoms } \\
\text { reduced in both } \\
\text { treatment groups, } \\
\text { with greater } \\
\text { reductions seen in } \\
\text { the COPE. There } \\
\text { were few clinically } \\
\text { meaningful PTSD } \\
\text { or SI exacerbations. } \\
\text { Approximately } 15 \% \\
\text { of the sample } \\
\text { experienced } \\
\text { exacerbations in } \\
\text { PTSD symptoms, } \\
\text { and } 13 \% \text { of the } \\
\text { sample experienced } \\
\text { exacerbations in SI. } \\
\text { There were no } \\
\text { significant } \\
\text { differences in } \\
\text { symptom } \\
\text { exacerbation } \\
\text { between groups. For } \\
\text { the study, reliable } \\
\text { exacerbation was } \\
\text { defined respectively } \\
\text { as } 6.11 \text { points on the } \\
\text { PCL-5 and .52 } \\
\text { points on the PHQ-9 } \\
\text { Item } 9 \text {. }\end{array}$ & Moderate \\
\hline \multicolumn{11}{|c|}{ Combined treatments } \\
\hline $\begin{array}{l}\text { Meyers et } \\
\text { al., } 2017\end{array}$ & $\begin{array}{l}33 \text { veterans with } \\
\text { PTSD and BPD } \\
\text { symptoms. } \\
\text { PTSD-related } \\
\text { trauma was not } \\
\text { reported. }\end{array}$ & $48.5 \%$ & $\begin{array}{l}\text { Outpatient, } \\
\text { combined } \\
\text { group and } \\
\text { individual }\end{array}$ & DBT-PE & $\begin{array}{l}\text { Not } \\
\text { reported, no } \\
\text { related } \\
\text { exclusion } \\
\text { criteria }\end{array}$ & $\begin{array}{l}\text { 12-week ITP. } \\
\text { DBT and PE } \\
\text { were provided } \\
\text { simultaneously, } \\
\text { consisting of } \\
\text { individual DBT } \\
\text { sessions and } 3 \\
\text { skills groups } \\
\text { each week in } \\
\text { addition to } 2 \mathrm{x} \\
\text { weekly } 90- \\
\text { minute sessions } \\
\text { of standard PE }\end{array}$ & PCL-C & BSSI & $\begin{array}{l}\text { PTSD and SI } \\
\text { significantly } \\
\text { reduced over the } \\
\text { course of treatment. } \\
\text { Specifically, } 91 \% \\
\text { showed a reliable } \\
\text { reduction in } \\
\text { symptoms and over } \\
\text { half of the sample } \\
\text { no longer screened } \\
\text { positive for PTSD } \\
\text { by the end of } \\
\text { treatment. }\end{array}$ & Weak \\
\hline
\end{tabular}




\begin{tabular}{|c|c|c|c|c|c|c|c|c|c|c|}
\hline & & & & & & $\begin{array}{l}\text { (beginning in } \\
\text { the second week } \\
\text { of the program, } \\
\text { with sessions } 1 \\
\text { and } 2 \text { being } \\
\text { group-based } \\
\text { educational } \\
\text { sessions). } \\
\text { Treatment was } \\
\text { augmented with } \\
\text { various } \\
\text { activities } \\
\text { including } \\
\text { mindfulness, } \\
\text { community } \\
\text { outings and/or } \\
\text { meetings, and } \\
\text { group-based } \\
\text { skills practice. }\end{array}$ & & & $\begin{array}{l}\text { Importantly, no } \\
\text { reports of self-harm, } \\
\text { suicide attempts, or } \\
\text { hospitalizations. }\end{array}$ & \\
\hline $\begin{array}{l}\text { Harned et } \\
\text { al., } 2012\end{array}$ & $\begin{array}{l}13 \text { women with } \\
\text { PTSD, BPD, } \\
\text { and recent } \\
\text { and/or imminent } \\
\text { suicidal } \\
\text { behavior or } \\
\text { serious NSSI } \\
\text { participated in } \\
\text { the study. The } \\
\text { women in the } \\
\text { sample reported } \\
\text { a range of index } \\
\text { traumas } \\
\text { including } \\
\text { childhood } \\
\text { sexual abuse, } \\
\text { adult rape, and } \\
\text { childhood } \\
\text { physical abuse. }\end{array}$ & $100 \%$ & $\begin{array}{l}\text { Outpatient, } \\
\text { combined } \\
\text { group and } \\
\text { individual }\end{array}$ & DBT-PE & $\begin{array}{l}\text { Not } \\
\text { reported, no } \\
\text { related } \\
\text { exclusion } \\
\text { criteria }\end{array}$ & $\begin{array}{l}\text { Participants } \\
\text { received DBT } \\
\text { with the addition } \\
\text { of PE, which } \\
\text { included one } \\
\text { year of standard } \\
\text { DBT (1 hour } \\
\text { individual + } 2.5 \\
\text { hours of group } \\
\text { skills training } \\
\text { weekly + phone } \\
\text { consultation). } \\
\text { The DBT-PE } \\
\text { protocol was } \\
\text { given during the } \\
\text { year once } \\
\text { patients } \\
\text { achieved control } \\
\text { over higher- } \\
\text { priority targets } \\
\text { such as not } \\
\text { being at } \\
\text { imminent risk of } \\
\text { suicide. } \\
\text { Participants }\end{array}$ & PSS-I & $\begin{array}{l}\text { SBQ; } \\
\text { SASII }\end{array}$ & $\begin{array}{l}\text { SI significantly } \\
\text { decreased over the } \\
\text { course of treatment. } \\
\text { Specifically, } \\
\text { approximately } 85 \% \\
\text { of treatment } \\
\text { completers and } 70 \% \\
\text { in the ITT group } \\
\text { experienced reliable } \\
\text { symptom } \\
\text { improvements. } \\
\text { Additionally, } \\
\text { approximately } 71 \% \\
\text { in the DBT + PE } \\
\text { group and } 60 \% \text { in } \\
\text { the ITT group no } \\
\text { longer met criteria } \\
\text { for PTSD at the end } \\
\text { of treatment. } \\
\text { Importantly, there } \\
\text { was no evidence of } \\
\text { exacerbation of } \\
\text { intentional self- } \\
\text { injury urges or } \\
\text { behaviors, PTSD }\end{array}$ & Moderate \\
\hline
\end{tabular}




\begin{tabular}{|c|c|c|c|c|c|c|c|c|c|c|}
\hline & & & & & & $\begin{array}{l}\text { received either } \\
\text { one combined } \\
\text { individual } \\
\text { therapy session } \\
\text { per week ( } 90 \\
\text { min of DBT-PE } \\
\text { and } 30 \text { min of } \\
\text { DBT) or } 2 \\
\text { individual } \\
\text { therapy sessions } \\
\text { per week (one } \\
90 \text { min DBT-PE } \\
\text { session and one } \\
60 \text { min DBT } \\
\text { session), as well } \\
\text { as group skills } \\
\text { training and as } \\
\text { needed phone } \\
\text { consultations. } \\
\text { DBT+DBT-PE } \\
\text { was compared to } \\
\text { DBT only. }\end{array}$ & & & $\begin{array}{l}\text { symptom severity, } \\
\text { treatment drop out, } \\
\text { or crisis service use. }\end{array}$ & \\
\hline $\begin{array}{l}\text { Harned et } \\
\text { al., } 2014\end{array}$ & $\begin{array}{l}26 \text { treatment- } \\
\text { seeking females } \\
\text { with BPD, } \\
\text { PTSD, and at } \\
\text { least two suicide } \\
\text { attempts or } \\
\text { NSSI episodes } \\
\text { within the past } 5 \\
\text { years with at } \\
\text { least one } \\
\text { episode in the } \\
\text { past } 8 \text { weeks. } \\
\text { Participants } \\
\text { endorsed a } \\
\text { range of traumas } \\
\text { including } \\
\text { childhood } \\
\text { sexual abuse, } \\
\text { adult rape, and } \\
\text { intimate partner } \\
\text { violence. }\end{array}$ & $100 \%$ & $\begin{array}{l}\text { Outpatient, } \\
\text { combined } \\
\text { group and } \\
\text { individual }\end{array}$ & $\begin{array}{l}\text { DBT }(n=9) \\
\text { or DBT + } \\
\text { DBT-PE } \\
(n=17)\end{array}$ & $\begin{array}{l}\text { Participants } \\
\text { were asked } \\
\text { to taper off } \\
\text { SSRIs } \\
\text { before DBT- } \\
\text { PE or remain } \\
\text { on a stable } \\
\text { dose during } \\
\text { DBT-PE. } \\
\text { Participants } \\
\text { matched for } \\
\text { randomizatio } \\
\text { n on current } \\
\text { SSRI use. } \\
\text { Standard } \\
\text { DBT } \\
\text { pharmacothe } \\
\text { rapy } \\
\text { procedure } \\
\text { used for all } \\
\text { medications } \\
\text { except }\end{array}$ & $\begin{array}{l}\text { Participants } \\
\text { were } \\
\text { randomized to } \\
\text { receive DBT or } \\
\text { DBT + DBT- } \\
\text { PE. Standard } \\
\text { DBT was used } \\
\text { (1 hour } \\
\text { individual + } 2.5 \\
\text { hours of group } \\
\text { skills training } \\
\text { weekly + phone } \\
\text { consultation). } \\
\text { DBT + DBT-PE } \\
\text { included either } \\
\text { one combined } \\
\text { individual } \\
\text { therapy session } \\
\text { per week (90 } \\
\text { min of DBT-PE } \\
\text { and } 30 \text { min of } \\
\text { DBT) or } 2\end{array}$ & PSS-I & SASII & $\begin{array}{l}\text { PTSD symptoms } \\
\text { severity } \\
\text { significantly } \\
\text { decreased over the } \\
\text { course of treatment. } \\
\text { Individuals who } \\
\text { received DBT + PE } \\
\text { reported } \\
\text { significantly greater } \\
\text { improvements than } \\
\text { those who received } \\
\text { DBT. Those in the } \\
\text { DBT+ PE group } \\
\text { were } 1.3 x \text { more } \\
\text { likely to report } \\
\text { reliable and } \\
\text { clinically significant } \\
\text { improvement and } 2 \mathrm{x} \\
\text { more likely to } \\
\text { achieve diagnostic } \\
\text { remission than those } \\
\text { in the DBT group. }\end{array}$ & Moderate \\
\hline
\end{tabular}




$\begin{array}{ll}\text { Harned et } & \text { 38 women with } \\ \text { al., 2018 } & \text { BPD and PTSD } \\ \text { **Comprise } & \text { and recent } \\ \text { d of Harned } & \text { suicidal } \\ \text { et al., 2012 } & \text { behavior or } \\ \text { and Harned } & \text { NSSI. Reported } \\ \text { et al., 2014 } & \text { index traumas } \\ \text { samples } & \text { were varied and } \\ & \text { included events } \\ & \text { such as } \\ & \text { childhood } \\ & \text { sexual abuse, } \\ & \text { adult rape, and } \\ & \text { childhood } \\ & \text { physical abuse. }\end{array}$

SSRIs. 88\%

of all

participants

had used

psychotropic

medication

in the past

year.

$\begin{array}{ll}100 \% & \begin{array}{l}\text { Outpatient, } \\ \text { combined } \\ \text { group and } \\ \text { individual }\end{array}\end{array}$

DBT or
DBT +
DBT-PE

See Harned

et al., 2012

and Harned

et al., 2014

therapy sessions

per week (one

90 min DBT-PE

session and one

60 min DBT

session), as well

as group skills

training and as

needed phone

consultations.

Individuals

could receive

the DBT-PE

protocol if or

when they

achieved control

over higher-

priority targets

such as not

being at

imminent risk of

suicide or

intentional self-

injury.

This study

combined

participants

from Harned et

al., 2012 and

Harned et al.,

2014 (with the

loss of one

participant in

2014 due to

consent error for

daily data).

Participants

enrolled in

either an open

trial of DBT +

DBT-PE

(Harned et al.,

2012) or a

Additionally, the

suicide attempt rate

was 1.4-2.4x lower

in the DBT + PE

group and the rate

of NSSI was 1.3-

$1.5 x$ lower in the

DBT + PE group

compared to the

DBT group.

Importantly, suicide

and self-injurious

behavior were not

exacerbated by

PTSD treatment.

\begin{tabular}{|c|c|c|}
\hline PCL-C & $\begin{array}{l}\text { Single } \\
\text { item to } \\
\text { assess } \\
\text { urges to } \\
\text { engage in } \\
\text { problem } \\
\text { behaviors } \\
\text { (e.g., } \\
\text { attempt } \\
\text { suicide) }\end{array}$ & $\begin{array}{l}\text { PTSD symptom } \\
\text { severity changed } \\
\text { significantly in the } \\
\text { second and third } \\
\text { stages of treatment. } \\
\text { Receipt of DBT + } \\
\text { PE resulted in } \\
\text { slightly larger but } \\
\text { non-significant } \\
\text { reductions in PTSD } \\
\text { symptoms in the } \\
\text { second and third } \\
\text { stage of treatment. } \\
\text { Both groups } \\
\text { experienced non- } \\
\text { significant } \\
\text { reductions in SI or } \\
\text { self-harm across the }\end{array}$ \\
\hline
\end{tabular}




$\begin{array}{ll}\text { Bohus et al., } & \text { 74 participants } \\ 2013 & \text { with and } \\ \text { **Kruger et } & \text { without BPD } \\ \text { al., 2014 } & \text { who had CSA- } \\ \text { reports } & \text { related, } \\ \text { secondary } & \text { treatment- } \\ \text { analysis } & \text { resistant PTSD } \\ \text { from this } & \text { Participants als } \\ \text { sample } & \text { had a comorbi } \\ & \text { eating disorder } \\ & \text { or major } \\ & \text { depressive } \\ & \text { disorder. }\end{array}$

randomized

controlled trial

(RCT)

comparing DBT

with and without

the DBT-PE

protocol

(Harned et al.,

2014).

$\begin{array}{ll}100 \% & \begin{array}{l}\text { Outpatient, } \\ \text { combined } \\ \text { group and } \\ \text { individual }\end{array} \\ \end{array}$

\begin{tabular}{|c|c|c|c|}
\hline DBT-PTSD & $\begin{array}{l}\text { No related } \\
\text { exclusion } \\
\text { criteria. } \\
\text { Psychiatrists } \\
\text { in both } \\
\text { treatment } \\
\text { arms used } \\
\text { clinical } \\
\text { expertise to } \\
\text { prescribe } \\
\text { psychotropic } \\
\text { medications. }\end{array}$ & $\begin{array}{l}\text { Individual DBT } \\
\text { ( } n=38 \text { ) with two } \\
\text { weekly 45- } \\
\text { minute } \\
\text { treatment } \\
\text { sessions and } \\
\text { additional } \\
\text { weekly group } \\
\text { sessions for } \\
\text { skills training, } \\
\text { self-esteem, } \\
\text { mindfulness, } \\
\text { and } \\
\text { psychoeducation } \\
\text { over a 12-week } \\
\text { period. } \\
\text { Augmentation } \\
\text { included } 3 \\
\text { additional non- } \\
\text { specific group } \\
\text { sessions (e.g., } \\
\text { music or art } \\
\text { therapy). } \\
\text { Treatment as } \\
\text { usual was a } \\
\text { waitlist } \\
\text { condition (TAU- } \\
\text { WL; } n=38 \text { ). }\end{array}$ & $\begin{array}{l}\text { CAPS- } \\
\text { IV; PDS }\end{array}$ \\
\hline
\end{tabular}

three phases of treatment.

Adverse
events
(e.g.,
suicide
attempts,
suicidal
ideation,
NSSIB)

and NSSI

behaviors decreased

over the course of

treatment.

Specifically,

participants who

received DBT

experienced large

symptom reductions

and did not

experience

increased PTSD

symptoms. Six

participants in the

waitlist condition

reported increased

PTSD symptoms.

Importantly, there

were no increases in

suicidal ideation or

suicide attempts

during the study

period.
Strong

$(2+2$

in




\begin{tabular}{|c|c|c|c|c|c|c|c|c|c|c|}
\hline $\begin{array}{l}\text { Steil et al., } \\
2018\end{array}$ & $\begin{array}{l}21 \text { adult females } \\
\text { who met criteria } \\
\text { for PTSD } \\
\text { related to } \\
\text { childhood } \\
\text { sexual abuse } \\
\text { (CSA) and who } \\
\text { met at least } 4 \\
\text { criteria for BPD. }\end{array}$ & $100 \%$ & $\begin{array}{l}\text { Outpatient, } \\
\text { individual }\end{array}$ & DBT-PTSD & $\begin{array}{l}81 \% \text { of } \\
\text { participants } \\
\text { received } \\
\text { psychophar } \\
\text { macological } \\
\text { medication } \\
\text { at the start of } \\
\text { treatment } \\
\text { and were } \\
\text { asked not to } \\
\text { change } \\
\text { medication } \\
\text { until after } \\
\text { follow-up. }\end{array}$ & $\begin{array}{l}\text { Participants } \\
\text { received up to } \\
24 \text { weekly } \\
\text { sessions. } \\
\text { Session length } \\
\text { varied between } \\
50 \text { and } 120 \\
\text { minutes, with no } \\
\text { more than } 40 \\
\text { treatment hours } \\
\text { per individual. } \\
\text { Participants } \\
\text { attended one } \\
\text { booster session } \\
6 \text { weeks after } \\
\text { treatment } \\
\text { completion. }\end{array}$ & $\begin{array}{l}\text { CAPS- } \\
\text { IV }\end{array}$ & $\begin{array}{l}\text { Severe } \\
\text { Behaviour } \\
\text { Dyscontro } \\
1 \\
\text { Interview } \\
\text { (SBD-I) }\end{array}$ & $\begin{array}{l}\text { PTSD symptoms } \\
\text { significantly } \\
\text { decreased over the } \\
\text { course of treatment, } \\
\text { and suicidality or } \\
\text { self-harm as } \\
\text { measured by the } \\
\text { SBD-I was not } \\
\text { exacerbated for any } \\
\text { of the study } \\
\text { participants. }\end{array}$ & Strong \\
\hline \multicolumn{11}{|c|}{ Suicide-focused treatments } \\
\hline $\begin{array}{l}\text { Rudd et al., } \\
2015\end{array}$ & $\begin{array}{l}152 \text { active-duty } \\
\text { soldiers with } \\
\text { current (past } \\
\text { week) SI with } \\
\text { intent to die } \\
\text { and/or a recent } \\
\text { (past month) } \\
\text { suicide attempt. } \\
\text { PTSD-related } \\
\text { trauma type not } \\
\text { reported. }\end{array}$ & $12.5 \%$ & $\begin{array}{l}\text { Outpatient, } \\
\text { individual }\end{array}$ & BCBT & $\begin{array}{l}\text { No related } \\
\text { exclusion } \\
\text { criteria. } \\
\text { TAU } \\
\text { included } \\
\text { medication. }\end{array}$ & $\begin{array}{l}\text { 12xweekly or } \\
\text { biweekly 60- } \\
\text { minute sessions } \\
\text { ( } n=76 \text {; except } \\
\text { for the first } \\
\text { session, which } \\
\text { was 90- } \\
\text { minutes). } \\
\text { Comparison } \\
\text { group was TAU } \\
\text { (included } \\
\text { individual } \\
\text { and/or group } \\
\text { psychotherapy, } \\
\text { psychiatric } \\
\text { medication, } \\
\text { substance abuse } \\
\text { treatment, } \\
\text { support groups; } \\
n=76 \text { ). }\end{array}$ & PCL-M & $\begin{array}{l}\text { SASII; } \\
\text { BSSI }\end{array}$ & $\begin{array}{l}\text { PTSD and SI } \\
\text { reduced over the } \\
\text { course of treatment. } \\
\text { Individuals } \\
\text { receiving BCBT } \\
\text { were } 60 \% \text { less } \\
\text { likely to attempt } \\
\text { suicide within } 2 \\
\text { years after treatment } \\
\text { completion. }\end{array}$ & Moderate \\
\hline
\end{tabular}




\begin{tabular}{|c|c|c|c|c|c|c|c|c|c|c|}
\hline $\begin{array}{l}\text { Ghahramanl } \\
\text { ou-Holloway } \\
\text { et al., } 2018\end{array}$ & $\begin{array}{l}24 \text { U.S. military } \\
\text { members and } \\
\text { adult } \\
\text { beneficiaries } \\
\text { who were } \\
\text { admitted to a } \\
\text { psychiatric } \\
\text { hospital due to a } \\
\text { recent suicidal } \\
\text { crisis. PTSD- } \\
\text { related trauma } \\
\text { type not } \\
\text { reported. }\end{array}$ & $42 \%$ & $\begin{array}{l}\text { Inpatient, } \\
\text { individual }\end{array}$ & PACT & $\begin{array}{l}\text { Not } \\
\text { reported, no } \\
\text { related } \\
\text { exclusion } \\
\text { criteria }\end{array}$ & $\begin{array}{l}6 \mathrm{x} 60-\text { to } 90- \\
\text { minute sessions } \\
\text { over three days. } \\
\text { All participants } \\
\text { also received } \\
\text { enhanced usual } \\
\text { care (EUC), } \\
\text { which included } \\
\text { a variety of } \\
\text { individual and } \\
\text { group-based } \\
\text { sessions, } \\
\text { recreation } \\
\text { therapy, art } \\
\text { therapy, and } \\
\text { medication } \\
\text { management. } \\
\text { This comprised } \\
\text { the PACT+EUC } \\
\text { group ( } n=12 \text { ), } \\
\text { compared to the } \\
\text { EUC group } \\
\text { ( } n=12 \text { ). }\end{array}$ & $\begin{array}{l}\text { PCL-M/- } \\
\mathrm{C}\end{array}$ & $\begin{array}{l}\text { C-SSRS; } \\
\text { SSI-WP }\end{array}$ & $\begin{array}{l}\text { PTSD symptoms } \\
\text { reduced over the } \\
\text { course of treatment. } \\
\text { Treatment groups } \\
\text { did not significantly } \\
\text { differ at any time } \\
\text { point on any given } \\
\text { measure. While } \\
\text { both groups overall } \\
\text { were equally likely } \\
\text { to show significant } \\
\text { decreases in PTSD } \\
\text { symptoms, } \\
\text { PACT+EUC } \\
\text { showed increased } \\
\text { likelihood for } \\
\text { significant symptom } \\
\text { reductions when } \\
\text { looking at high-risk } \\
\text { participants only. } \\
\text { Those in } \\
\text { PACT+EUC were } \\
\text { more likely to have } \\
\text { significant } \\
\text { reductions in } \\
\text { suicidal ideation. } 5 \\
\text { participants (17\% } \\
\text { PACT+EUC; } 25 \% \\
\text { EUC) made at least } \\
1 \text { suicide attempt } \\
\text { during follow-up, } \\
\text { but between-groups } \\
\text { re-attempt status did } \\
\text { not significantly } \\
\text { differ. There were } \\
\text { no deaths by suicide } \\
\text { during the study. }\end{array}$ & Moderate \\
\hline $\begin{array}{l}\text { LaCroix et } \\
\text { al., } 2018\end{array}$ & $\begin{array}{l}36 \text { military } \\
\text { service members } \\
\text { or adult } \\
\text { beneficiaries } \\
\text { who were } \\
\text { psychiatrically } \\
\text { hospitalized due }\end{array}$ & $30.6 \%$ & $\begin{array}{l}\text { Inpatient, } \\
\text { individual }\end{array}$ & PACT & $\begin{array}{l}\text { Not } \\
\text { reported, no } \\
\text { related } \\
\text { exclusion } \\
\text { criteria }\end{array}$ & $\begin{array}{l}\text { Participants } \\
\text { were } \\
\text { randomized to } \\
\text { PACT }(n=18) \\
\text { with combined } \\
\text { with enhanced } \\
\text { usual care }\end{array}$ & $\begin{array}{l}\text { PCL-M } \\
\text { or PCL- } \\
\text { C }\end{array}$ & $\begin{array}{l}\text { C-SSRS; } \\
\text { SSI }\end{array}$ & $\begin{array}{l}\text { PTSD symptoms } \\
\text { reduced over the } \\
\text { course of treatment. } \\
\text { A greater proportion } \\
\text { of individuals in the } \\
\text { PACT + enhanced } \\
\text { usual care group }\end{array}$ & Moderate \\
\hline
\end{tabular}


to a recent

suicide attempt

and had a

documented

inpatient

admission

record of ASD

or PTSD.

Trauma type

was not

specified.
(EUC) or EUC

only $(n=18)$.

Both were

delivered over

the course of a

psychiatric stay.

PACT consisted

of

approximately 6

60- to 90-min

sessions

delivered over 3

days. EUC

varied based on

the individual

but commonly

included group

psychotherapy,

recreation

therapy, art

therapy, and

medication

management

Psychiatric

inpatients in

military

treatment

facilities also

have access to

military

chaplains and

may be visited

by family,

friends, and

members of

their chain of

command. experienced

clinically significant

PTSD symptom

change (100\%)

compared to the

enhanced usual care

group (38\%). Over

the course of the 3 -

month follow-up

period, three

participants $(17 \%)$

in the PACT +

enhanced usual care

group and two

participants $(11 \%)$

in the enhanced

usual care group

made at least one

subsequent suicide

attempt following

psychiatric

discharge. Results

indicated no

significant

differences in

reattempt status for

participants in the

PACT + enhanced

usual care group

compared with the

enhanced usual care

group. No

participants in the

PACT enhanced

usual care group

and one participant

in the enhanced

usual care group

died by suicide

during the follow-up

period. 


\begin{tabular}{|c|c|c|c|c|c|c|c|c|c|c|}
\hline $\begin{array}{l}\text { Harned et } \\
\text { al., } 2010 \\
\text { *Linehan et } \\
\text { al., } 2006\end{array}$ & $\begin{array}{l}51 \text { adult women } \\
\text { with BPD and at } \\
\text { least two suicide } \\
\text { attempts and/or } \\
\text { nonsuicidal self- } \\
\text { injuries within } \\
\text { the past } 5 \text { years } \\
\text { with at least one } \\
\text { episode in the } \\
\text { past } 8 \text { weeks. } \\
51 \% \text { of the } \\
\text { sample also met } \\
\text { criteria for } \\
\text { PTSD. Those } \\
\text { with PTSD } \\
\text { endorsed a } \\
\text { range of index } \\
\text { traumas } \\
\text { including } \\
\text { childhood } \\
\text { physical abuse, } \\
\text { childhood } \\
\text { sexual abuse, } \\
\text { and adult sexual } \\
\text { assault. }\end{array}$ & $100 \%$ & $\begin{array}{l}\text { Outpatient, } \\
\text { combined } \\
\text { group and } \\
\text { individual }\end{array}$ & DBT & $\begin{array}{l}\text { Not } \\
\text { reported, no } \\
\text { related } \\
\text { exclusion } \\
\text { criteria }\end{array}$ & $\begin{array}{l}12 \text { months of } \\
\text { DBT, which } \\
\text { included } 1 \\
\text { hour/week of } \\
\text { individual } \\
\text { psychotherapy, } \\
2.5 \text { hours/week } \\
\text { of group skills } \\
\text { training, and } \\
\text { phone } \\
\text { consultations as } \\
\text { needed. }\end{array}$ & $\begin{array}{l}\text { SCID-IV } \\
\text { PTSD } \\
\text { module }\end{array}$ & $\begin{array}{l}\text { SBQ; } \\
\text { SASII }\end{array}$ & $\begin{array}{l}\text { Imminent SI and } \\
\text { recent NSSI } \\
\text { decreased } \\
\text { significantly over } \\
\text { the course of } \\
\text { treatment. The } \\
\text { presence of co- } \\
\text { occurring PTSD did } \\
\text { not attenuate DBT's } \\
\text { impact on suicidal } \\
\text { and self-injuring } \\
\text { behaviors. Between } \\
80-100 \% \text { of } \\
\text { participants who } \\
\text { experienced reduced } \\
\text { SI continued to } \\
\text { meet criteria for } \\
\text { PTSD. }\end{array}$ & Strong \\
\hline
\end{tabular}

Note. $*$ Parent study; $* *$ Related to another study. Weak $=$ Two or more weak component ratings. Moderate $=$ One weak component rating. Strong $=$ No weak component ratings. ASD: Acute Stress Disorder. AUD: Alcohol Use Disorder. BCBT: Brief Cognitive Behavioral Therapy. BDI-II: Beck Depression InventoryII. BPD: Borderline Personality Disorder. BSS: Beck Scale for Suicide Ideation. C-SSRS: Columbia-Suicide Severity Rating Scale. CAPS-IV: Clinician Administered PTSD Scale for DSM-IV. CAPS-5: Clinician Administered PTSD Scale for DSM-V. CBT: Cognitive Behavioral Therapy. CG: Complicated Grief. CMS: Civilian Mississippi Scale for PTSD. COPE: Concurrent Treatment of PTSD and Substance Use Disorders Using Prolonged Exposure. CPT: Cognitive Processing Therapy. CSA: Childhood Sexual Abuse. DBT: Dialectical Behavior Therapy. EMDR: Eye Movement Desensitization and Reprocessing therapy. ITP: Intensive Treatment Program. ITT: Intent to Treat. NET: Narrative Exposure Therapy. NSSI: Non-Suicidal Self-Injury. OEF: Operation Enduring Freedom. OIF: Operation Iraqi Freedom. OQ-45: Outcome Questionnaire 45. PACT: Post Admission Cognitive Therapy. PCL-IV: PTSD Symptom Checklist for DSM-IV. PCL-5: PTSD Symptom Checklist for DSM-V. PCL-C: PTSD Symptom Checklist - Civilian Version. PCL-M: PTSD Symptom Checklist - Military Version. PCL-S: PTSD Symptom Checklist - Specific. PCT: Present-Centered Therapy. PDS: Posttraumatic Diagnostic Scale. PE: Prolonged Exposure. PHQ-9: Patient Health Questionnaire-9. PSS-I: PTSD Symptom Scale - Interview. PSS-SR: PTSD Symptom Scale - Self-Report. PTSD: Posttraumatic Stress Disorder. RCT: Randomized Controlled Trial. SASII: Suicide Attempt Self-Injury Interview. SBQ: Suicide Behaviors Questionnaire. SCID-IV: Structured Clinical Interview for DSM-IV. SCS: Suicide Crisis Syndrome. SI: Suicidal Ideation. SS: Seeking Safety. SSI: Scale for Suicide Ideation. SSI-WP: Scale for Suicide Ideation-Worst. SSRI: Selective Serotonin Reuptake Inhibitor. TAU: Treatment as Usual. TBI: Traumatic Brain Injury. TF: Trauma-Focused. VA: Veterans Affairs. VRE:

Virtual Reality Exposure. WL: Waitlist. 